\title{
2013 Update on Sea Otter Studies to Assess Recovery from the 1989 Exxon Valdez Oil Spill, Prince William Sound, Alaska
}

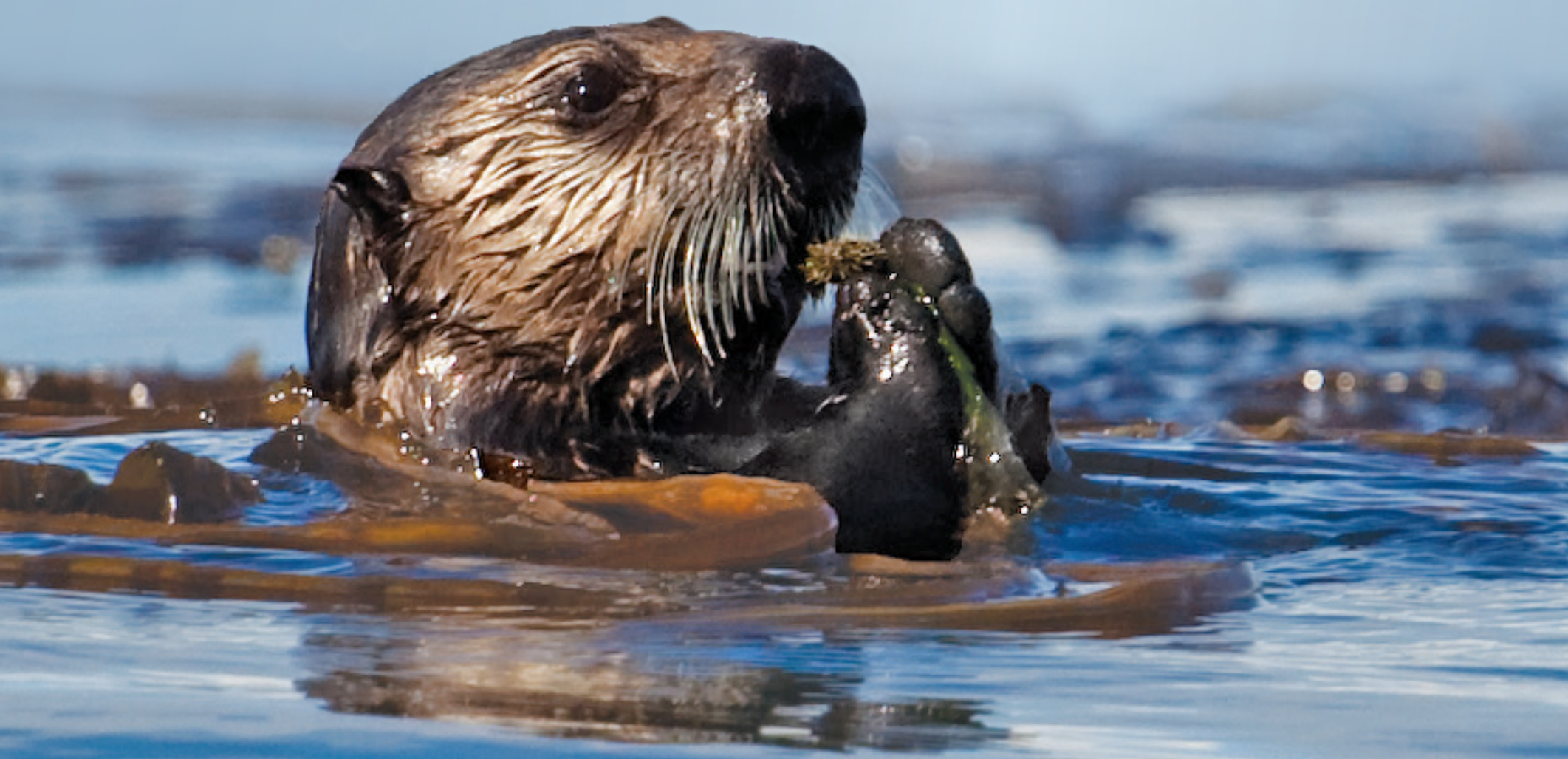

Open-File Report 2014-1030

U.S. Department of the Interior

U.S. Geological Survey 
Cover: Sea otter in kelp. Photograph by Benjamin Weitzman, U.S. Geological Survey. 


\section{Update on Sea Otter Studies to Assess Recovery from the 1989 Exxon Valdez Oil Spill, Prince William Sound, Alaska}

By B.E. Ballachey, D.H. Monson, G.G. Esslinger, K. Kloecker, J. Bodkin, L. Bowen, and A.K. Miles

Open-File Report 2014-1030

U.S. Department of the Interior

U.S. Geological Survey 


\title{
U.S. Department of the Interior SALLY JEWELL, Secretary
}

\section{U.S. Geological Survey Suzette M. Kimball, Acting Director}

\author{
U.S. Geological Survey, Reston, Virginia: 2014
}

\begin{abstract}
For more information on the USGS-the Federal source for science about the Earth, its natural and living resources, natural hazards, and the environment-visit http://www.usgs.gov or call 1-888-ASK-USGS

For an overview of USGS information products, including maps, imagery, and publications, visit $h$ ttp://www.usgs.gov/pubprod
\end{abstract}

To order this and other USGS information products, visit $h$ ttp://store.usgs.gov

\author{
Suggested citation: \\ Ballachey, B.E., Monson, D.H., Esslinger, G.G., Kloecker, K., Bodkin, J., Bowen, L., and Miles, A.K., \\ 2014, 2013 update on sea otter studies to assess recovery from the 1989 Exxon Valdez oil spill, Prince \\ William Sound, Alaska: U.S. Geological Survey Open-File Report 2014-1030, 40 p., \\ http://dx.doi.org/10.3133/ofr20141030. \\ ISSN 2331-1258 (online)
}

Any use of trade, product, or firm names is for descriptive purposes only and does not imply endorsement by the U.S. Government.

Although this report is in the public domain, permission must be secured from the individual copyright owners to reproduce any copyrighted material contained within this report. 


\section{Contents}

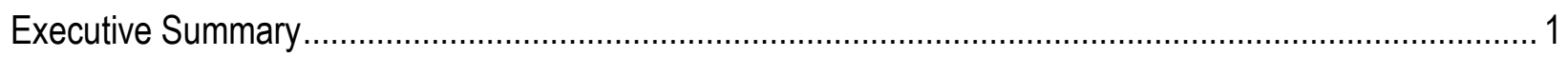

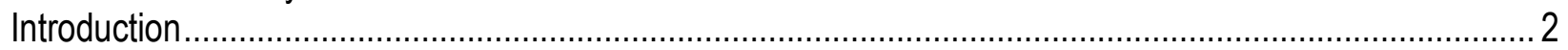

Chapter 1. Sea Otter Abundance in Western Prince William Sound through 2013 …................................ 5

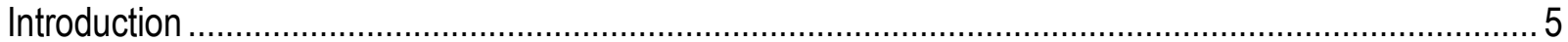

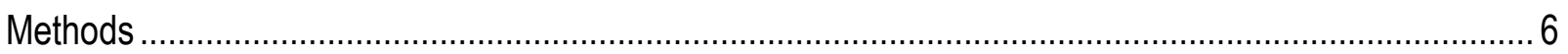

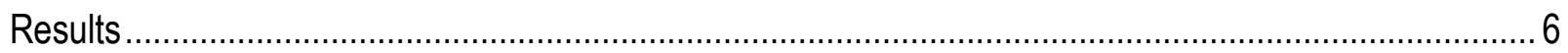

Chapter 2. Age Distributions of Sea Otters Found Dead in Western Prince William Sound, Alaska,

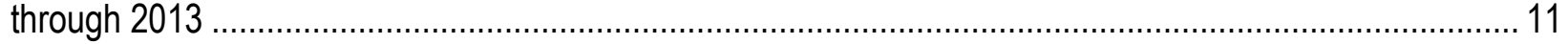

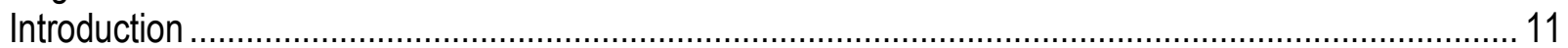

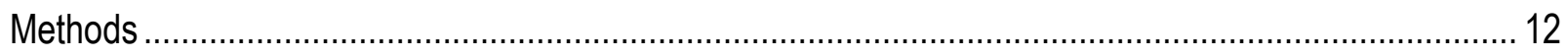

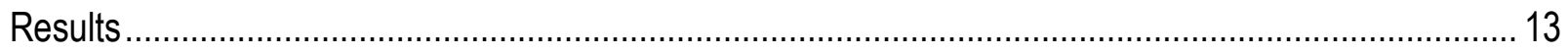

Discussion.............................................................................................................. 15

Chapter 3. Gene Transcript Profiles in Sea Otters from Prince William Sound, Alaska, 2008 and 2012, and

Clinically Normal and Wild Reference Sea Otters............................................................................. 17

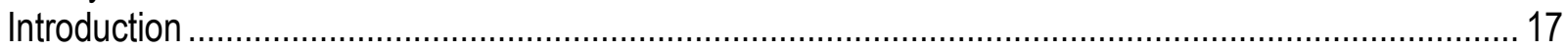

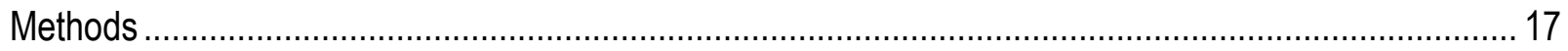

Free-Ranging Target Sea Otters ........................................................................................... 17

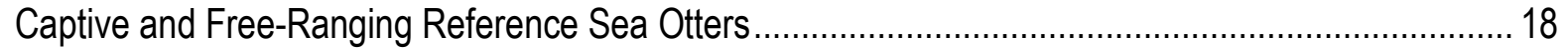

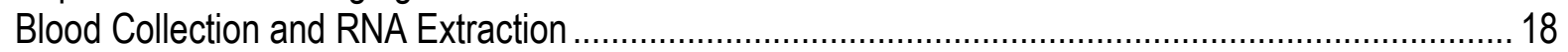

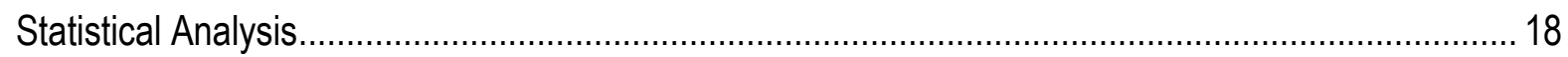

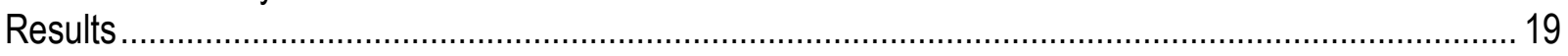

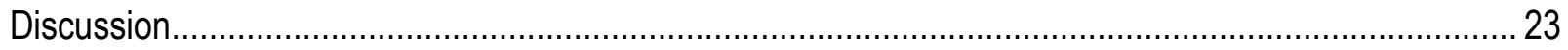

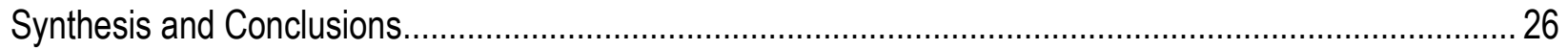

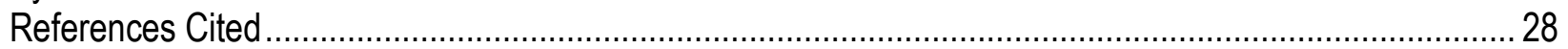

Appendix 1. Publications and Reports on Sea Otter Oil Spill Studies, Authored or Co-authored by

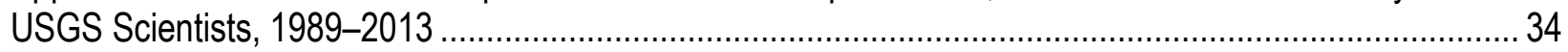

\section{Figures}

Figure 1. Map of Prince William Sound showing sea otter study areas ................................................... 3

\section{Chapter 1}

Figure 1.1. Prince William Sound (PWS), Alaska.

Figure 1.2. Trend in sea otter abundance ( \pm standard error) in western Prince William Sound, Alaska, 1993-2013

Figure 1.3. Estimated numbers of sea otters ( \pm standard error) at heavily oiled northern Knight Island, Prince William Sound, Alaska, 1993-2013, compared to the pre-spill abundance estimate (Dean and others, 2000)...

Figure 1.4. Estimated numbers of sea otters ( \pm standard error) at the unoiled Montague Island study area, Prince William Sound, Alaska, 1993-2012

\section{Chapter 2}

Figure 2.1. Relative age distributions of sea otter carcasses collected on western Prince William Sound beaches from 1976 to 2013. 
Figure 2.2. Relative proportion of prime-age animals (2-8 yrs-old) in age distributions of sea otter carcasses collected on western Prince William Sound beaches from 1976 to 2013.

\section{Chapter 3}

Figure 3.1. Multivariate, nonparametric, multidimensional scaling of gene transcription profiles (see table 3.1 for description of genes) of sea otters sampled at three locations in western Prince William Sound, Alaska, 2008 and 2012, the Alaska Peninsula, and in captivity at aquaria

Figure 3.2. Distribution of average cycle threshold (CT) values across genes targeted by the panel of 13 primer sets

\section{Tables}

\section{Chapter 1}

Table 1.1. Estimates of sea otter numbers based on aerial surveys in western Prince William Sound, 1993-2013, including estimates for the heavily oiled Knight Island and unoiled Montague Island intensive study areas

\section{Chapter 3}

Table 3.1. Function of 13 genes identified in free-ranging sea otters sampled in western Prince William Sound, Alaska, in 2008 and 2012, and Alaska Peninsula in 2009, and in clinically normal captive sea otters sampled in 2008,2009 , or 2010

\section{Conversion Factors and Datum}

\section{Conversion Factors}

SI to Inch/Pound

\begin{tabular}{lll}
\hline & Multiply & \\
\hline & Length & To obtain \\
\hline meter $(\mathrm{m})$ & 3.281 & foot $(\mathrm{ft})$ \\
kilometer $(\mathrm{km})$ & 0.6214 & mile $(\mathrm{mi})$ \\
\hline & Area & \\
\hline square kilometer $\left(\mathrm{km}^{2}\right)$ & 0.3861 & square mile $\left(\mathrm{mi}^{2}\right)$ \\
\hline & Mass & \\
\hline gram $(\mathrm{g})$ & 0.03527 & ounce, avoirdupois $(\mathrm{oz})$ \\
kilogram $(\mathrm{kg})$ & 2.205 & pound avoirdupois $(\mathrm{lb})$ \\
\hline & Volume & \\
\hline liter $(\mathrm{L})$ & 0.2642 & gallon (gal) \\
\hline
\end{tabular}

Temperature in degrees Celsius $\left({ }^{\circ} \mathrm{C}\right)$ may be converted to degrees Fahrenheit $\left({ }^{\circ} \mathrm{F}\right)$ as follows:

${ }^{\circ} \mathrm{F}=\left(1.8 x^{\circ} \mathrm{C}\right)+32$.

\section{Datum}

Horizontal coordinate information is referenced to the North American Datum of 1983 (NAD 83). 


\title{
2013 Update on Sea Otter Studies to Assess Recovery from the 1989 Exxon Valdez Oil Spill, Prince William Sound, Alaska
}

\author{
By B.E. Ballachey, D.H. Monson, G.G. Esslinger, K. Kloecker, J. Bodkin, L. Bowen, and A.K. Miles
}

\section{Executive Summary}

On March 24, 1989, the tanker vessel Exxon Valdez ran aground in Prince William Sound, Alaska, spilling an estimated 42 million liters of Prudhoe Bay crude oil. Oil spread in a southwesterly direction and was deposited on shores and waters in western Prince William Sound (WPWS). The sea otter (Enhydra lutris) was one of more than 20 nearshore species considered to have been injured by the spill. Since 1989, the U.S. Geological Survey has led a research program to evaluate effects of the spill on sea otters and assess progress toward recovery, as defined by demographic and biochemical indicators. Here, we provide an update on the status of sea otter populations in WPWS, presenting findings through 2013. To assess recovery based on demographic indicators, we used aerial surveys to estimate abundance and annual collections of sea otter carcasses to evaluate patterns in ages-at-death. To assess recovery based on biochemical indicators, we quantified transcription rates for a suite of genes selected as potential indicators of oil exposure in sea otters based on laboratory studies of a related species, the mink (Mustela vison). In our most recent assessment of sea otter recovery, which incorporated results from a subset of studies through 2009, we concluded that recovery of sea otters in WPWS was underway. This conclusion was based on increasing abundance throughout WPWS, including increasing numbers at northern Knight Island, an area that was heavily oiled in 1989 and where the local sea otter population had previously shown protracted injury and lack of recovery. However, we did not conclude that the WPWS sea otter population had fully recovered, due to indications of continuing reduced survival and exposure to lingering oil in sea otters at Knight Island, at least through 2009. Based on data available through 2013, we now conclude that the status of sea otters - at all spatial scales within WPWS - is consistent with the designation of recovery from the spill as defined by the Exxon Valdez Oil Spill Trustee Council. The support for this conclusion is based primarily on demographic data, including (1) a return to estimated pre-spill abundance of sea otters at northern Knight Island, and (2) a return to pre-spill mortality patterns. Gene transcription rates in 2012 were similar in sea otters from oiled, moderately oiled and unoiled areas, suggesting abatement of exposure effects in 2012. However, because 2012 gene transcription rates generally were low for sea otters from all areas relative to 2008, we cannot fully interpret these observations without data from a wider panel of genes. This slight uncertainty with respect to the data from the biochemical indicator is outweighed by the strength of the data for the demographic indicators. The return to pre-spill numbers and mortality patterns suggests a gradual dissipation of lingering oil over the past two decades, to the point where continuing exposure is no longer of biological significance to the WPWS sea otter population. 


\section{Introduction}

On March 24, 1989, the tanker vessel Exxon Valdez ran aground on Bligh Reef in northeastern Prince William Sound (PWS), Alaska (fig. 1), spilling an estimated 42 million L of Prudhoe Bay crude oil (Spies and others, 1996). At that time, the Exxon Valdez oil spill (EVOS) was the largest recorded accidental release of oil into U.S. waters. Oil spread in a southwesterly direction, leaving a heavy layer on many beaches within western Prince William Sound (WPWS) before exiting Montague Strait and other passages at the southwestern corner of PWS (Galt and Payton, 1990). Islands in the central part of WPWS, particularly the Knight Island complex, were in the direct path of the moving oil and relatively close to the source, and thus were heavily contaminated. Oil eventually covered more than $26,000 \mathrm{~km}^{2}$ of water in WPWS and the Gulf of Alaska and contaminated more than $1,900 \mathrm{~km}$ of coastline (Morris and Loughlin, 1994; Spies and others, 1996).

Much of the area affected by the spill was prime sea otter (Enhydra lutris) habitat. Sea otters were particularly vulnerable to acute effects of the spilled oil as they rely on their pelage rather than blubber for insulation, and oil drastically reduces the insulative value of the fur (Costa and Kooyman, 1982; Siniff and others, 1982). Within days of the spill, many live and dead oiled sea otters were captured or collected by spill response personnel, and nearly 1,000 sea otter deaths were documented over the months following the spill. However, not all carcasses were recovered and the total number of sea otters that succumbed to acute injuries has been estimated to be as high as several thousand (Ballachey and others, 1994).

Following initial injury assessment, research to evaluate the process and progress toward recovery of injured species and ecosystems identified unexpected delays for several species that occupy nearshore habitats (Peterson and others, 2003; Rice and others, 2007), including sea otters. Concerns about long-term lack of recovery of sea otters in WPWS led to implementation of an extensive and diverse series of post-spill studies that has spanned the 24 years since the spill. Recovery of sea otters has been defined by the Exxon Valdez Oil Spill Trustee Council as:

"... when the population in oiled areas returns to conditions that would have existed had the spill not occurred and when biochemical indicators of hydrocarbon exposure in otters in the oiled areas are similar to those in otters in unoiled areas. An increasing population trend and normal reproduction and age structure in western Prince William Sound will indicate that recovery is underway" (Exxon Valdez Oil Spill Trustee Council, 2010; www.evostc.state.ak.us/Recovery/status.cfm). 


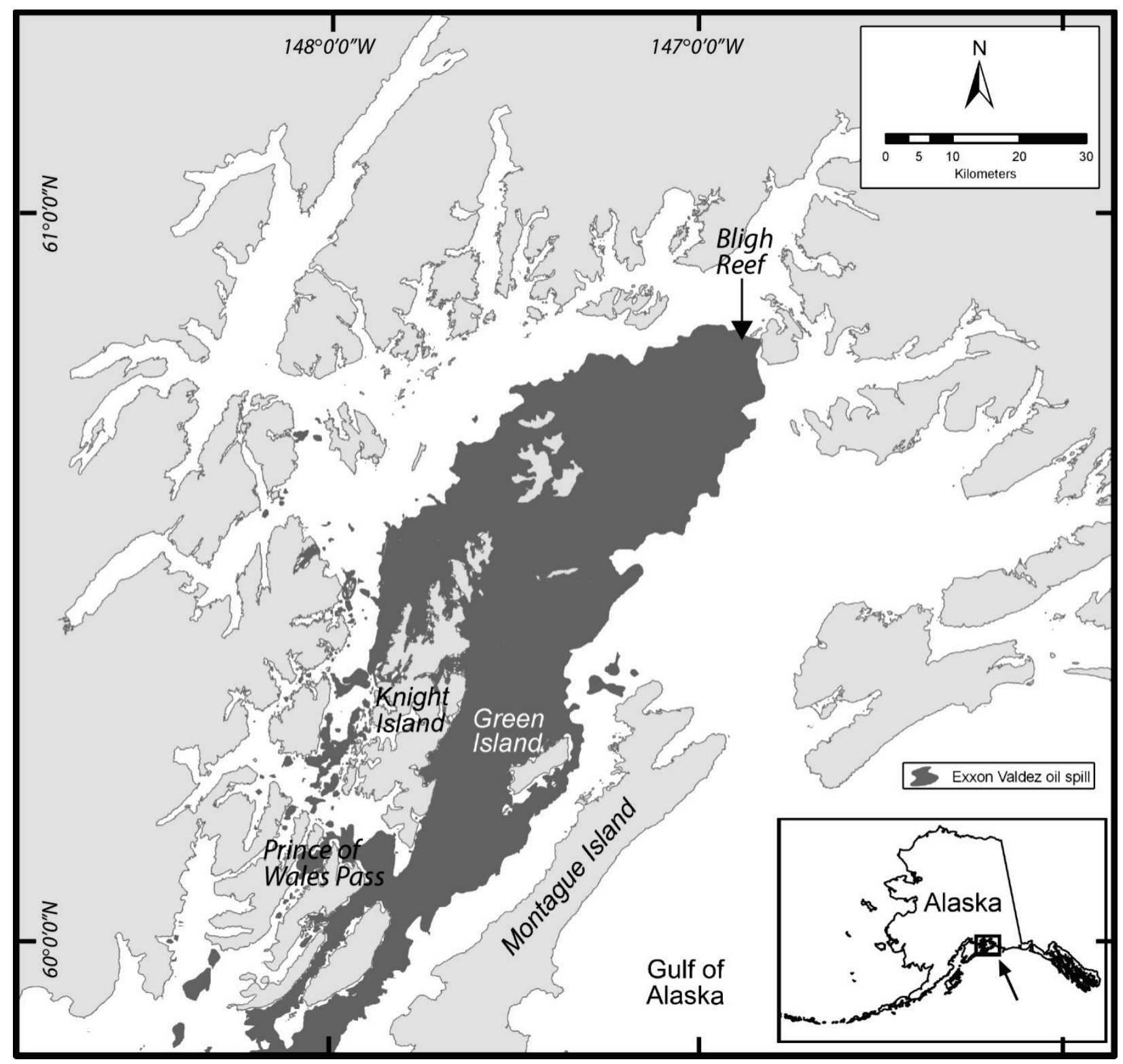

Figure 1. Map of Prince William Sound showing sea otter study areas. The dark gray area represents the extent of the spilled oil coverage in the Prince William Sound in 1989. 
Findings of sea otter studies by the U.S. Geological Survey have been presented in multiple publications (appendix 1). Briefly, sea otter abundance in heavily oiled WPWS remained depressed, at about one-half the pre-spill estimate, with no evidence of recovery through 2005 (Bodkin and others, 2002, 2011). Reduced survival rates appeared to be the proximate factor for delayed sea otter recovery (Monson and others, 2000, 2011; Ballachey and others, 2003). Food limitation was discounted as contributing to that reduced survival, whereas chronic exposure to residual oil was implicated as a concern (Bodkin and others, 2002; Dean and others, 2002; Peterson and Holland-Bartels, 2002; Bodkin and others, 2012).

Several lines of evidence demonstrated that oil from the spill persisted in the environment longer than anticipated. In 2001, Short and others $(2004,2006)$ documented unexpected amounts $(>55,000 \mathrm{~kg})$ of Exxon Valdez oil remaining in intertidal habitats in WPWS, and estimated that subsurface oil might persist at some sites for several decades (Short and others, 2007). Studies of mussels and clams, both common prey items of sea otters foraging in intertidal habitats, indicated that lingering oil was bioavailable as late as 2002 (Fukuyama and others, 2000; Thomas and others, 2007). As recently as 2008, sea otters from WPWS showed elevated transcription in several genes consistent with potential recent and chronic exposure to organic contaminants (Miles and others, 2012). Evidence of exposure to lingering oil through metabolic pathways also has been documented in other nearshore species, including harlequin duck (Histrionicus histrionicus; Trust and others, 2000; Esler and others, 2010), Barrow's goldeneye (Bucephala islandica; Trust and others, 2000; Esler and others, 2011), pigeon guillemot (Cepphus columba; Golet and others, 2002) and two nearshore fishes - the masked greenling (Hexagrammos octogrammus) and the crescent gunnel (Pholis laeta) (Jewett and others, 2002).

Considering all data collected through 2009, we concluded that the body of evidence for sea otters suggested recovery in the spill area of PWS was underway but not yet complete (Bodkin and others, 2011, 2012; Monson and others, 2011; Miles and others, 2012). The finding of progress toward recovery was based on increased abundance of sea otters in the area of northern Knight Island in WPWS in 2009, following almost two decades of reduced numbers relative to estimated pre-spill numbers (Bodkin and others, 2011). Evidence for continuing exposure to lingering oil in the environment remained, based on potential for exposure to oil lingering in intertidal habitats (Bodkin and others, 2012), persistent depressed survival of sea otters in oiled areas (Monson and others, 2011), and molecular measures suggesting exposure to organic contaminants for sea otters in oiled areas (Miles and others, 2012).

In this report, we update findings on three aspects of long-term sea otter studies:

1. Aerial surveys of abundance in WPWS through 2013 (Chapter 1; update of Bodkin and others, 2011);

2. Ages-at-death, based on annual recovery of sea otter carcasses on shorelines of WPWS through 2013 (Chapter 2; update of data presented in Monson and others, 2011);

3. Gene transcription analyses of sea otters in oiled and unoiled areas of WPWS through 2012 (Chapter 3; update of Miles and others, 2012).

The report concludes with a synthesis and conclusions section in which we integrate findings from the three chapters. 


\section{Chapter 1. Sea Otter Abundance in Western Prince William Sound through 2013}

By G.G. Esslinger, B.E. Ballachey, and J.L. Bodkin

\section{Introduction}

The 1989 Exxon Valdez oil spill (EVOS) caused significant sea otter mortality in western Prince William Sound (WPWS), both in the immediate weeks and months post-spill (Ballachey and others, 1994) and over longer time frames (years and decades; Monson and others, 2011). To assess recovery of sea otters, the Exxon Valdez Oil Spill Trustee Council established both demographic and biochemical criteria. As part of our effort to assess recovery based on demographic indicators, we used aerial surveys to estimate abundance in WPWS, including at the heavily oiled area of northern Knight Island and at Montague Island, an unoiled reference area (fig. 1.1).

At the time of the spill, survey data on the abundance of sea otters in WPWS were lacking. Aerial survey methods were developed after the spill (Bodkin and Udevitz, 1999), and annual surveys commenced in 1993. Our approach for assessing demographic recovery based on abundance was to consider overall trend (increasing, decreasing, or stable), and the time point at which the estimated number of new otters in the population was equal to or greater than the number of otters estimated to have died in the immediate aftermath of the spill. Acute spillrelated mortality estimates for WPWS ranged from 750 (Garshelis, 1997) to 2,650 sea otters (Garrott and others, 1993). For northern Knight Island, Dean and others (2000) estimated prespill abundance to be 165 sea otters, based on the number of carcasses collected, an estimated number of unrecovered carcasses, and the number of sea otters removed for rehabilitation.

A comprehensive analysis of results of aerial surveys from 1993 to 2009 was presented by Bodkin and others (2011). They found that numbers of sea otters in WPWS increased through 2000 at an average annual rate of 4 percent. However, at northern Knight Island, where oiling was heaviest and sea otter mortality highest, no increase in abundance was evident by 2000 . A continued significant increase in abundance was observed in WPWS between 2001 and 2009, with an average annual rate of increase from 1993 to 2009 of 2.6 percent. The 2009 estimate of numbers of sea otters in WPWS was 3,958 (standard error=653), nearly 2,000 more than the first post-spill estimate in 1993. Surveys between 2003 and 2009 also identified a significant increasing trend at heavily oiled northern Knight Island, averaging about 25 percent annually and resulting in a 2009 estimate of 116 sea otters (standard error=19). This 2009 abundance estimate was about 30 percent less than the pre-spill estimate of 165 sea otters, but was interpreted as evidence of progress toward recovery of sea otters in the most heavily oiled areas of WPWS.

Here, we update aerial survey results of Bodkin and others (2011) with data from 2011 to 2013, and evaluate trends in sea otter abundance in WPWS, including northern Knight Island. 


\section{Methods}

Consistent with prior sea otter surveys in WPWS, we used an aerial survey method developed specifically for estimating sea otter abundance (Bodkin and Udevitz, 1999). As part of the survey design, a combination of water depth and distance from shore is used to divide sea otter habitat into high and low density strata (fig. 1.1). Transects are spaced systematically within strata according to expected sea otter densities and time available to conduct the survey. The 400-m wide strip transects are surveyed by a pilot and an observer in a fixed-wing aircraft at an altitude of $91 \mathrm{~m}$ and an airspeed of $65 \mathrm{mph}$. Because sea otters can be difficult to sight in areas with kelp and usually are not visible when they dive underwater to gather prey, intensive searches are conducted periodically throughout the survey area to estimate the proportion of sea otters being detected on the transects. The detection probability is used to adjust the estimate of abundance.

For the WPWS survey, the same set of transects was surveyed from 1995 to 2013, once for each survey year (fig. 1.1) except in 2001, 2006, and 2010. To increase precision in estimates for the intensive oiled (northern Knight Island) and unoiled (Montague Island) study areas, up to five replicate surveys were conducted each year (except in 1993, 1994, 2006, and 2010 for both areas, and in 2013 at Montague Island) using the same techniques described in Bodkin and Udevitz (1999). Each replicate survey was randomly selected from 18 possible combinations of 3 high density and 6 low density sets of spatially unique transects. During each survey, data were entered using a custom survey application (Doug Burn, U.S. Fish and Wildlife Service, Anchorage, Alaska) in ArcPad $^{\circledR}$ (ESRI ${ }^{\circledR}$, Inc., Redlands, Calif.) on a Toughbook ${ }^{\circledR}$ laptop computer (Panasonic ${ }^{\circledR}$, Secaucus, N.J.). Survey data were post-processed in $\operatorname{ArcMap}^{\mathrm{TM}}$ (ESRI $^{\circledR}$, Inc.) and SAS ${ }^{\circledR} 9.2$ (SAS Institute ${ }^{\complement}$, Cary, N.C.) to estimate abundance and associated variance at different spatial scales. To estimate population growth rate for WPWS, we used linear regression (PROC GLM, SAS Institute ${ }^{\mathbb{C}}$, Cary, N.C.) to fit log-transformed population estimates weighted by standard errors.

\section{Results}

Results of aerial surveys conducted from 1993 to 2013 are summarized in table 1.1. Since aerial surveys designed specifically to estimate sea otter abundance began in 1993, numbers of sea otters in WPWS have increased at an average annual growth rate of 3 percent (fig. 1.2). Consistent with the upward trend in WPWS, numbers of sea otters at both the Knight Island (2011-2013; fig. 1.3) and Montague Island (2011-2012; fig. 1.4) study areas were elevated in recent years. The three most recent WPWS abundance estimates (2011-2013) represent an increase of about 850-2,200 sea otters since 1993 (table 1.1). Numbers of sea otters at northern Knight Island in 2011-2013 are similar to the pre-spill estimate of 165 (fig. 1.3). 


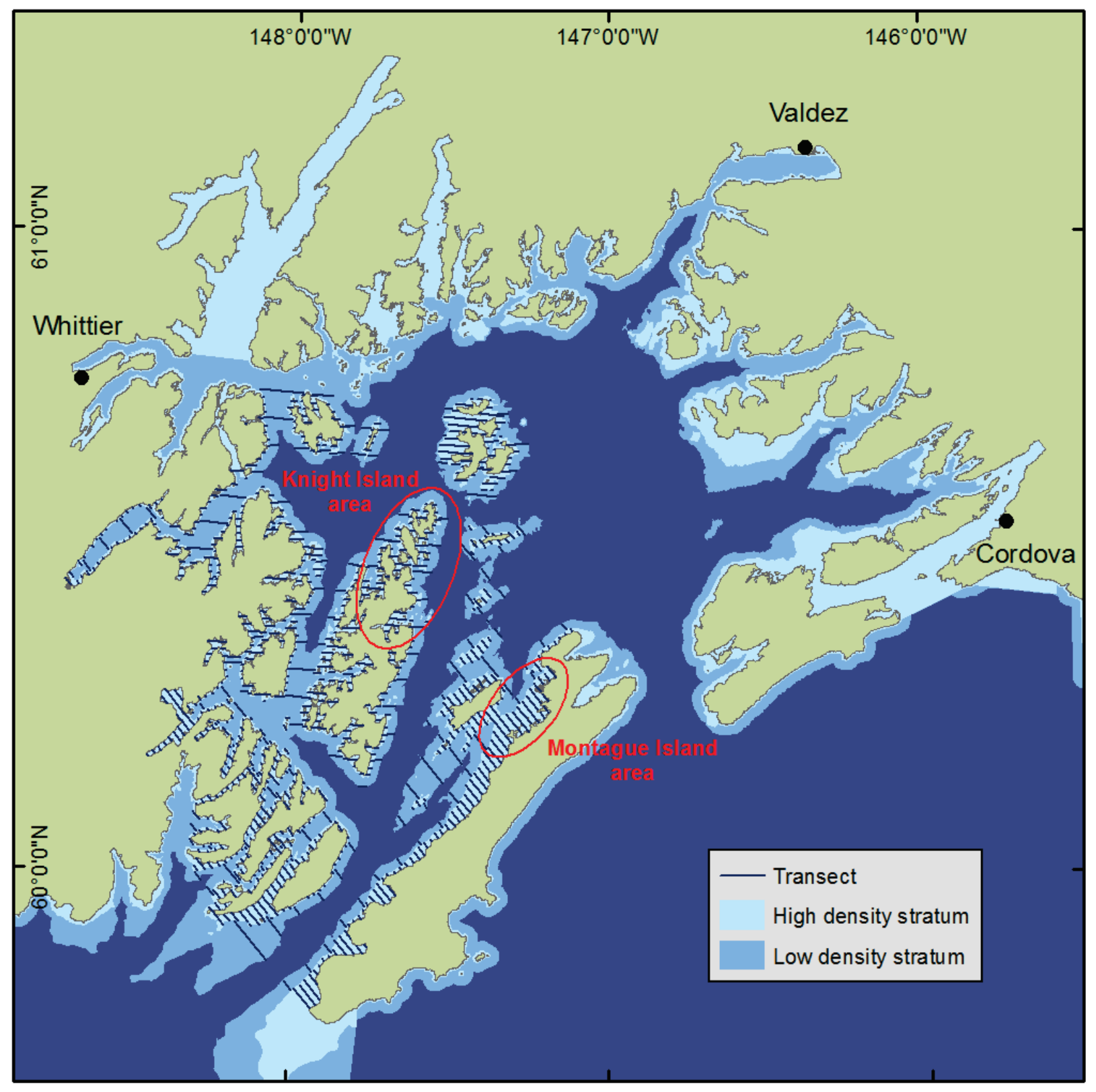

Figure 1.1. Prince William Sound (PWS), Alaska. Blue lines delineate the western PWS survey transects and collectively represent the survey area. Red ovals indicate general location of the intensive study areas at northern Knight Island (oiled area) and Montague Island (unoiled area) where up to five replicate surveys were conducted each survey year. The high density stratum is defined by water depths less than $40 \mathrm{~m}$ or $400 \mathrm{~m}$ from shore, whichever is greater. The low density stratum extends from the 40- to 100-m depth contour or $2 \mathrm{~km}$ from shore, whichever is greater. The high density stratum was sampled at a higher intensity (1,200 $\mathrm{m}$ between transects) than the low density stratum (4,800 m between transects). 
Table 1.1. Estimates of sea otter numbers based on aerial surveys in western Prince William Sound, 1993-2013, including estimates for the heavily oiled Knight Island and unoiled Montague Island intensive study areas.

$[-$, no estimate $]$

\begin{tabular}{|c|c|c|c|c|c|c|}
\hline \multirow[b]{2}{*}{ Year } & \multicolumn{2}{|c|}{ Western PWS } & \multicolumn{2}{|c|}{ Knight Island } & \multicolumn{2}{|c|}{ Montague Island } \\
\hline & $\begin{array}{c}\text { Abundance } \\
\text { estimate }\end{array}$ & $\begin{array}{l}\text { Standard } \\
\text { error }\end{array}$ & $\begin{array}{c}\text { Abundance } \\
\text { estimate }\end{array}$ & $\begin{array}{l}\text { Standard } \\
\text { error }\end{array}$ & $\begin{array}{c}\text { Abundance } \\
\text { estimate }\end{array}$ & $\begin{array}{l}\text { Standard } \\
\text { error }\end{array}$ \\
\hline 1993 & 2,054 & 698 & 75 & - & 335 & - \\
\hline 1994 & 2,228 & 356 & 78 & - & 303 & - \\
\hline 1995 & 2,185 & 225 & 89 & 22 & 297 & 50 \\
\hline 1996 & 2,180 & 218 & 65 & 13 & 382 & 39 \\
\hline 1997 & 2,341 & 202 & 76 & 19 & 595 & 31 \\
\hline 1998 & 3,119 & 494 & 76 & 16 & 623 & 92 \\
\hline 1999 & 2,475 & 381 & 81 & 15 & 586 & 109 \\
\hline 2000 & 2,658 & 294 & 79 & 6 & 544 & 95 \\
\hline 2001 & - & - & 79 & 20 & 659 & 189 \\
\hline 2002 & 1,840 & 334 & 38 & 11 & 369 & 48 \\
\hline 2003 & 2,631 & 540 & 26 & 8 & 619 & 46 \\
\hline 2004 & 2,704 & 315 & 54 & 17 & 561 & 86 \\
\hline 2005 & 2,751 & 311 & 37 & 14 & 725 & 105 \\
\hline 2006 & - & - & - & - & - & - \\
\hline 2007 & 2,380 & 372 & 71 & 14 & 356 & 58 \\
\hline 2008 & 3,609 & 635 & 98 & 24 & 589 & 162 \\
\hline 2009 & 3,958 & 653 & 116 & 29 & 310 & 62 \\
\hline 2010 & - & - & - & - & - & - \\
\hline 2011 & 2,896 & 392 & 169 & 30 & 662 & 224 \\
\hline 2012 & 3,459 & 448 & 152 & 28 & 995 & 136 \\
\hline 2013 & 4,277 & 638 & 139 & 33 & - & - \\
\hline
\end{tabular}




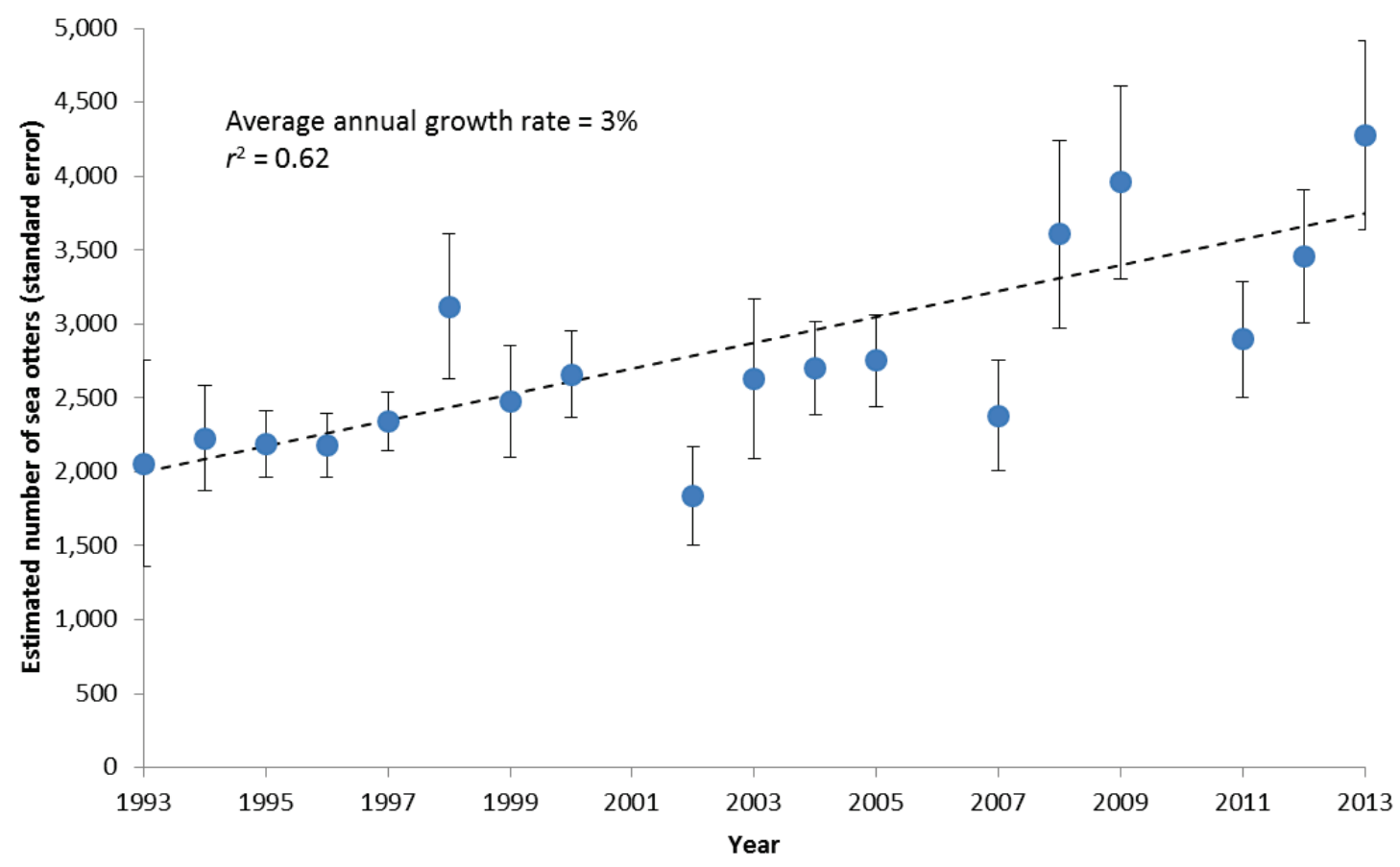

Figure 1.2. Trend in sea otter abundance ( \pm standard error) in western Prince William Sound, Alaska, 1993-2013.

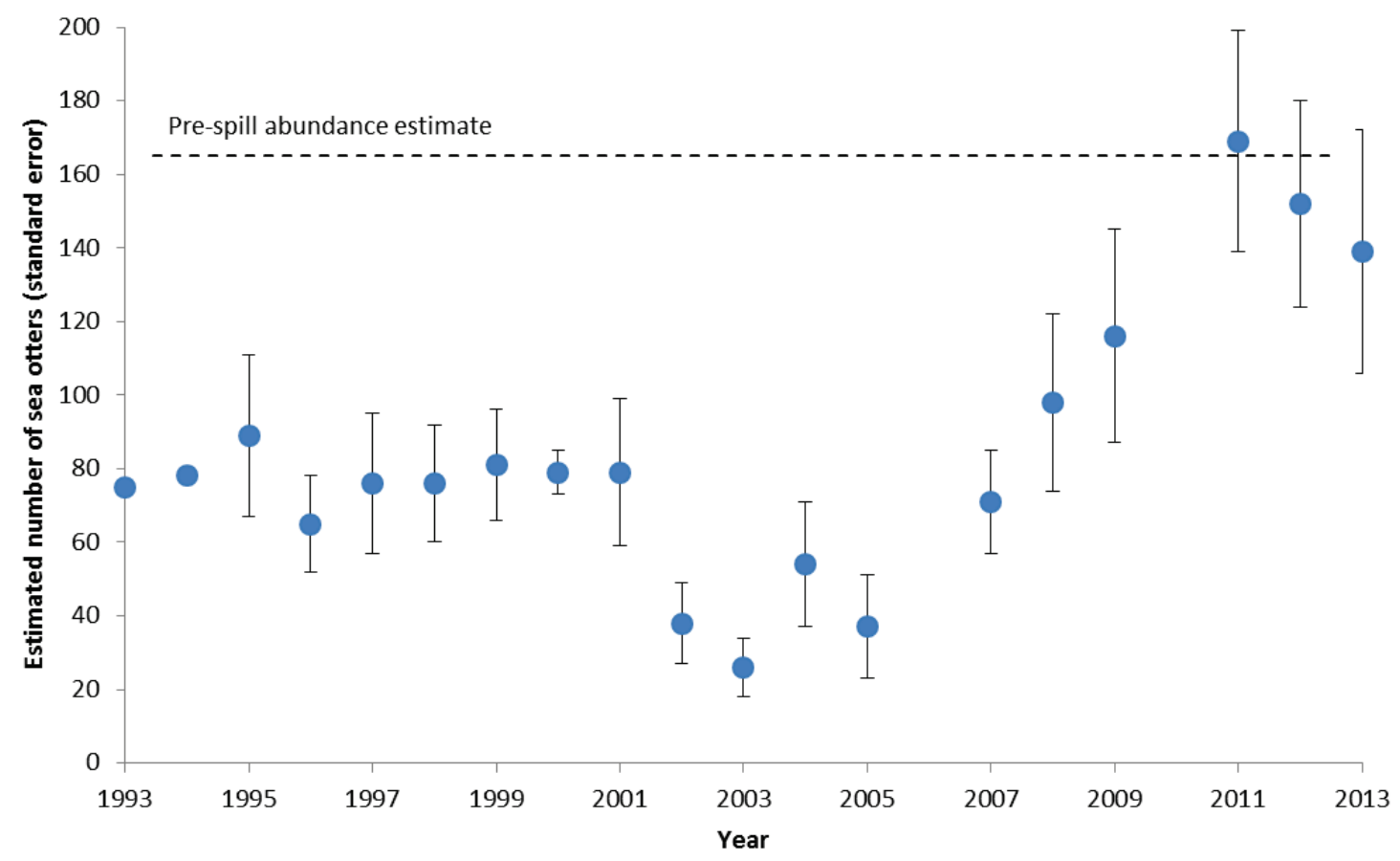

Figure 1.3. Estimated numbers of sea otters ( \pm standard error) at heavily oiled northern Knight Island, Prince William Sound, Alaska, 1993-2013, compared to the pre-spill abundance estimate (Dean and others, 2000). 


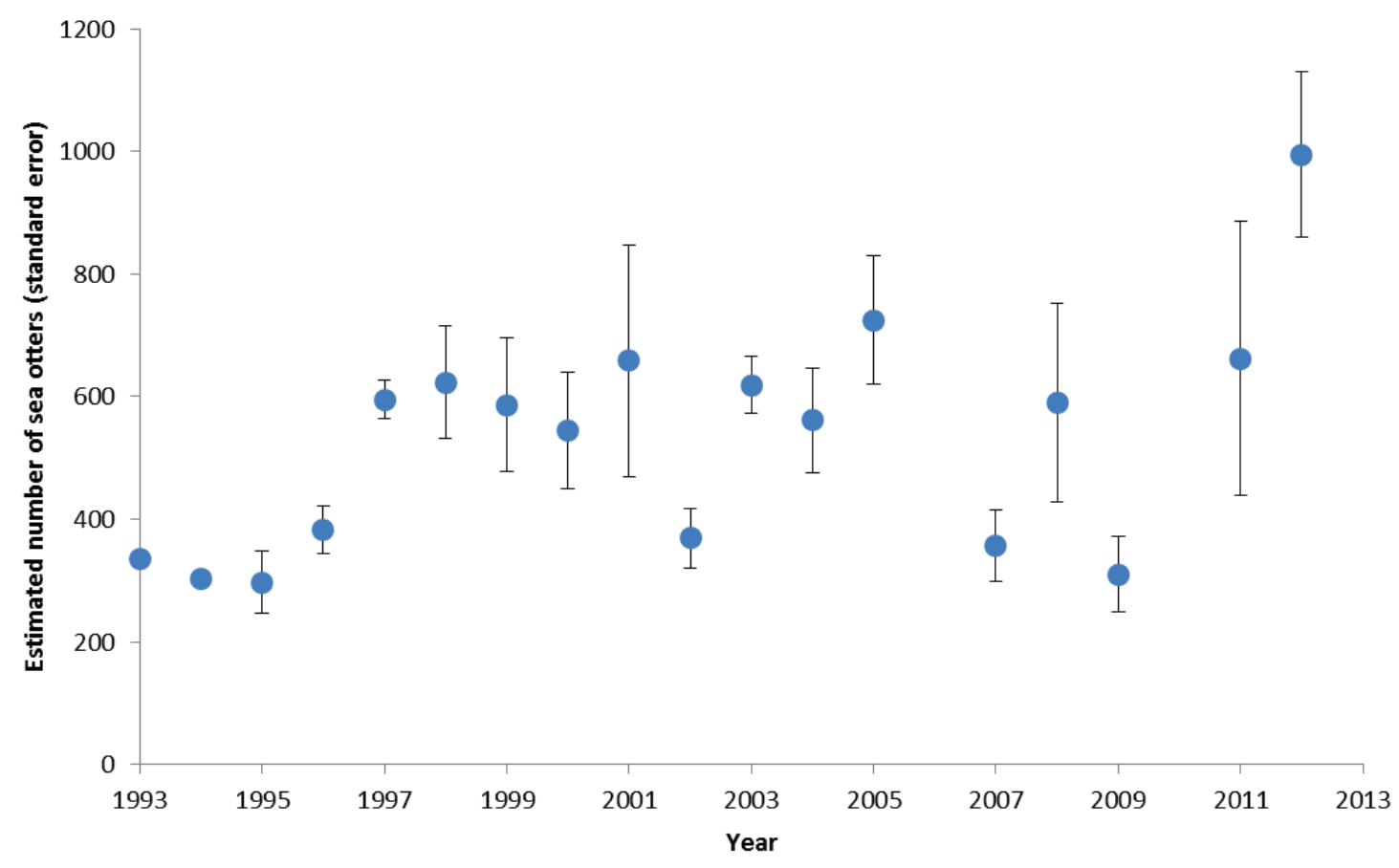

Figure 1.4. Estimated numbers of sea otters ( \pm standard error) at the unoiled Montague Island study area, Prince William Sound, Alaska, 1993-2012.

\section{Discussion}

Following their recovery from the commercial fur harvests and reoccupation of WPWS prior to 1970, sea otters were thought to be at or near equilibrium density prior to the spill (Bodkin and others, 2000). However, no surveys were conducted in WPWS just prior to the spill, and accurate data on abundance of sea otters in the area were not available. Survey methods were developed in the first post-spill years (Bodkin and Udevitz, 1999) and implemented in 1993. To determine whether WPWS sea otter numbers had recovered from the spill, we used estimates of acute mortality from the spill, and considered when the number of otters that died immediately after the spill had been replaced. By this measure, the increased abundance of sea otters in WPWS was consistent with recovery by 2009, following almost a decade of population growth.

At the heavily oiled northern Knight Island study area, however, the point at which sea otter abundance recovered to the pre-spill abundance apparently was delayed relative to WPWS overall. The abundance estimates at northern Knight Island did not exceed the estimated pre-spill level until 2011, and the 2012 and 2013 survey results were consistent with the 2011 finding (no survey data are available for 2010). Thus by 2011, for both WPWS and northern Knight Island, the aerial survey data indicate that sea otter abundance is consistent with the definition of population recovery from the spill. 


\title{
Chapter 2. Age Distributions of Sea Otters Found Dead in Western Prince William Sound, Alaska, through 2013
}

\author{
By D.H. Monson
}

\section{Introduction}

In spring 1989, the Exxon Valdez oil spill (EVOS) resulted in acute mortality of 1,000 to several thousand sea otters in western Prince William Sound (WPWS) and the central Gulf of Alaska (Ballachey and others, 1994). The spill also left crude oil in the intertidal zone in unconsolidated sediments of some WPWS beaches (Morris and Loughlin, 1994; Spies and others, 1996), some of which remained for more than two decades (Boufadel and others, 2010; Li and Boufadel, 2010; Xia and others, 2010). As sea otters forage, they excavate clams and other intertidal invertebrates, which can re-suspend buried oil and function as a pathway for chronic exposure of sea otters to toxic oil residues remaining in the environment (Bodkin and others, 2012). Surveys of sea otters indicated that numerical recovery in the most heavily oiled areas did not occur until approximately two decades post-spill (Chapter 1, this report). Extensive studies (appendix 1) suggested that delayed sea otter recovery was due to chronic exposure to oil, likely through effects on survival (Monson and others, 2000, 2011) rather than food limitation, reproductive constraints, or other alternative explanations.

To assess recovery of sea otters, the Exxon Valdez Oil Spill Trustee Council established both demographic and biochemical criteria. As part of our effort to assess recovery based on demographic indicators, we estimated abundance using aerial surveys (Chapter 1). We also continued collections of sea otter carcasses, a monitoring practice that began in WPWS in the 1970s. Age distributions of recovered carcasses can be used to describe trends and patterns in mortality of wild mammal populations (Caughley, 1966). Generally, mortality patterns of longlived mammals include peaks in young and old age classes, with lower mortality in the primeage class (Caughley, 1966; Emlen, 1970; Siler, 1979; Eberhardt, 1985). Sea otters are relatively long-lived, attaining ages of 15-20 years (Riedman and Estes, 1990), and follow this general pattern, with most natural mortality occurring in young and old age classes (Kenyon, 1969).

Based on age distributions of beach-cast sea otter carcasses collected each spring prior to the spill, the sea otter population in WPWS fit the previously described pattern with most natural mortality occurring in young and old age classes (Monson and others, 2000). Monson and others (2000) used the age distribution data to quantify the long-term effects of the oil spill on survival of sea otters. They found that from 1989 to 1998, survival of sea otters in WPWS was lower than pre-spill estimates, and that the magnitude of the difference was related to both age class of animals and time since the spill. Generally, survival of juveniles was low during the first few years following the spill while prime-age and old-age survival rates were less affected. Over time, juvenile survival increased, while survival of prime-age and old-age animals decreased (Monson and others, 2000). Decreases in survival were not limited to animals alive at the time of the spill (that is, individuals that potentially survived acute exposure), indicating that chronic exposure to residual contaminants in the environment continued to affect animals born in or 
migrating into oiled habitats. Low survival of tagged juvenile sea otters following the spill (Monnett and Rotterman, 1995; Ballachey and others, 2003) and discovery of elevated activity of biomarkers associated with hydrocarbon exposure in other nearshore species (Esler and others, 2002, 2010, 2011; Golet and others, 2002; Jewett and others, 2002; Bowyer and others, 2003; Ricca and others, 2010) provided additional evidence that reduced survival may have been caused by lingering oil.

Only a portion of the WPWS sea otter population appeared to be experiencing decreased survival rates, creating a population sink that continued to limit the rate of recovery of the entire WPWS population through at least 2005 (Monson and others, 2011). Source-sink models fit to mortality data collected through 2008 found no indication that elevated mortality had ceased by 2008 (Monson and others, 2011). However, survey data indicated that significant increases in sea otter abundance occurred in the heavily oiled areas between 2005 and 2013 (Bodkin and others, 2011; Chapter 1, this report) suggesting that mortality effects may have modulated during the late 2000s (Monson and others, 2011). Here, we present age distributions of carcasses collected through 2013, and show that mortality patterns in WPWS have returned to "normal," defined as the pre-spill pattern of mortality.

\section{Methods}

Sea otter carcass collections from 1976 through 2008 have been described previously (Monson and others, 2000, 2011), and similar collections continued from 2010 through 2013. Green Island (fig. 1), which was oiled in 1989, was the site of pre-spill collections, and carcass collections were continued there through 2013. Beginning in 1996, in addition to Green Island collections, carcasses were collected from shorelines throughout WPWS that received heavy oiling in 1989, including areas where residual oil was found through at least 2008 (Short and others, 2004, 2006, 2007; U.S. Geological Survey, unpub. data, 2008). Because the sex of dead animals often could not be determined, sexes were combined when examining age-at-death distributions. Skulls were collected when present, and a tooth (preferentially a premolar) removed for age analysis, although pups ( $<1$ year old) also were identified by open skull sutures and deciduous teeth (Schneider, 1973). Longitudinal sections of each tooth were decalcified for cementum annuli readings, generally providing age estimates \pm 1 year (Bodkin and others, 1997). Matson's Laboratory (Milltown, Mont.) sectioned and aged all teeth.

Kolmogorov-Smirnov (K-S) tests (Sokal and Rohlf, 1995) were used to compare the 2010-2013 age distribution to four other distributions including: (1) pre-spill (1974-1989), (2) spill-year (1989), (3) 1990-1993, and (4) 1994-2008. The two post-spill distributions (19901993 and 1994-2008) corresponded to two distinct periods of mortality pattern shifts identified by Monson and others (2011). Specifically, 1990-1993 was characterized by very low juvenile survival and only slightly reduced survival in the prime-age and old-age classes (Monson and others, 2011). In contrast, 1994-2008 was characterized by relatively normal juvenile survival but declining survival rates in the older age classes (Monson and others, 2011). For graphical presentation, age distributions were lumped into three age classes including - (1) juveniles (0age pups and 1-yr-old juveniles), (2) prime-age (2-8-yr-olds), and (3) old-age ( $>8 \mathrm{yr}$ ), and variability was calculated as simultaneous confidence intervals for multinomial proportions (Quesenberry and Hurst, 1964). The age range for "prime-age" was defined based on pre-spill age-at-death data and prior to any post-spill carcass collections. Subsequent statistical models (Udevitz and Ballachey, 1998) supported our definition of "old-age" beginning at 9 years of age (that is, the first year adult survival began to decrease under normal conditions). For K-S tests, 
ages were not lumped although 0 -age animals were excluded because small pups are easily removed by scavengers and thus are known to be under-represented in carcass collections. As a result, yearly variability in proportions of 0 -age animals may be influenced as much by variability in scavenging rates as actual mortality rates (Bodkin and Jameson, 1991).

Variability in the proportion of prime-age animals in the carcass collections was examined over time by plotting this proportion for each year with equal to or greater than five individuals in each age-class. For years with small sample sizes, defined as any age class having less than five individuals, that year's collection was combined with the following year, providing the combination did not cross any previously established "boundary" points (that is, 1989, 1993, and 2008, based on findings in Monson and others, 2011). If a small sample size distribution occurred at the boundary point, it was combined with the previous year's collection.

\section{Results}

From 2010 to 2013, 166 carcasses were recovered and had ages-at-death determined (fig. 2.1). In 2010, the proportion prime-age was high (0.56) and appeared similar to collections made in the previous 8-9 years (fig. 2.2). However, the 2010 sample was too small $(n=18)$ for valid statistical comparisons and could not be combined a priori with the previous (1994-2008) grouping, and thus was included with the 2011-2013 data to form the most recent grouping. As a whole, the 2010-2013 distribution differed significantly from the spill-year distribution (K-S $\left.d_{\max }=0.29, p<0.0001\right)$ and the 1994-2008 post-spill distribution (K-S $\left.d_{\max }=0.17, p=0.025\right)$ but not from the 1990-1993 post-spill distribution (K-S $d_{\max }=0.17, p=0.14$; fig. 2.1 ). The 2010 2013 distribution also did not differ from the 1976-1989 pre-spill distribution (K-S $d_{\text {max }}=0.12$, $p=0.33$; fig. 2.1), which is significant because it is the first post-spill grouping that did not differ from the pre-spill distribution. The 1989 spill year distribution was significantly different from all other age distributions $\left(\mathrm{K}-\mathrm{S} d_{\max }>0.16, p<0.05\right)$ while the 1990-1993 and 1994-2008 postspill distributions both differed from the 1976-1989 pre-spill distribution (K-S $d_{\max }>0.23$, $p<0.01)$ and did not differ from each other (K-S $\left.d_{\max }=0.11, p=0.4\right)$ (fig. 2.1).

When the proportion of prime-age otters in the annual carcass collections is compared across years (fig. 2.2), lower proportions are noted for 2010-2013 relative to the proportions in collections from the previous decade. The 2010-2013 proportions are similar to those noted in the pre-spill collections. 


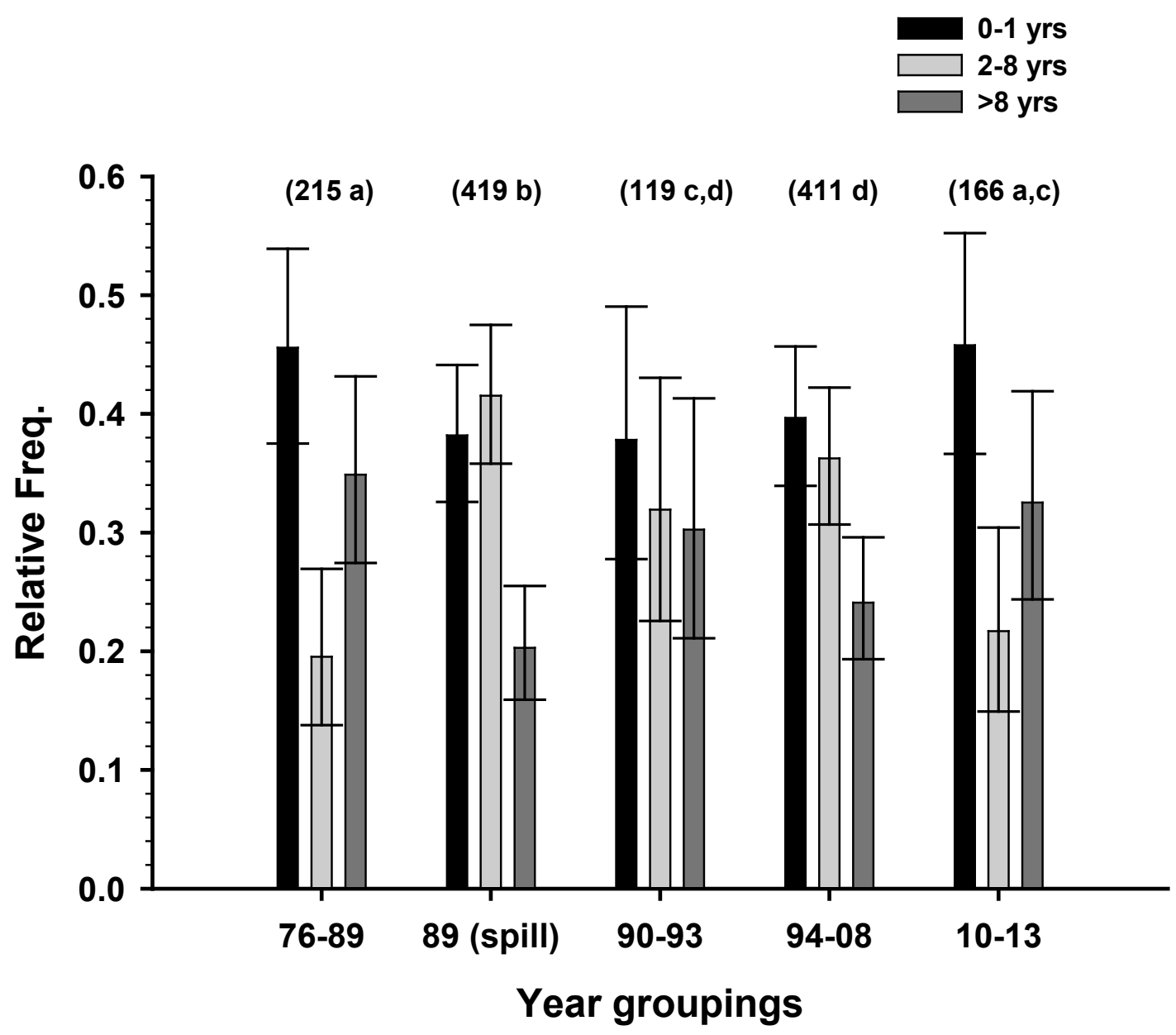

Figure 2.1. Relative age distributions of sea otter carcasses collected on western Prince William Sound beaches from 1976 to 2013. All non-pup ages were estimated by tooth cementum analysis (Matson's Laboratory, Milltown, Mont.). Total numbers of carcasses collected are in parentheses above each grouping and distributions with the same letter do not differ significantly from each other. 


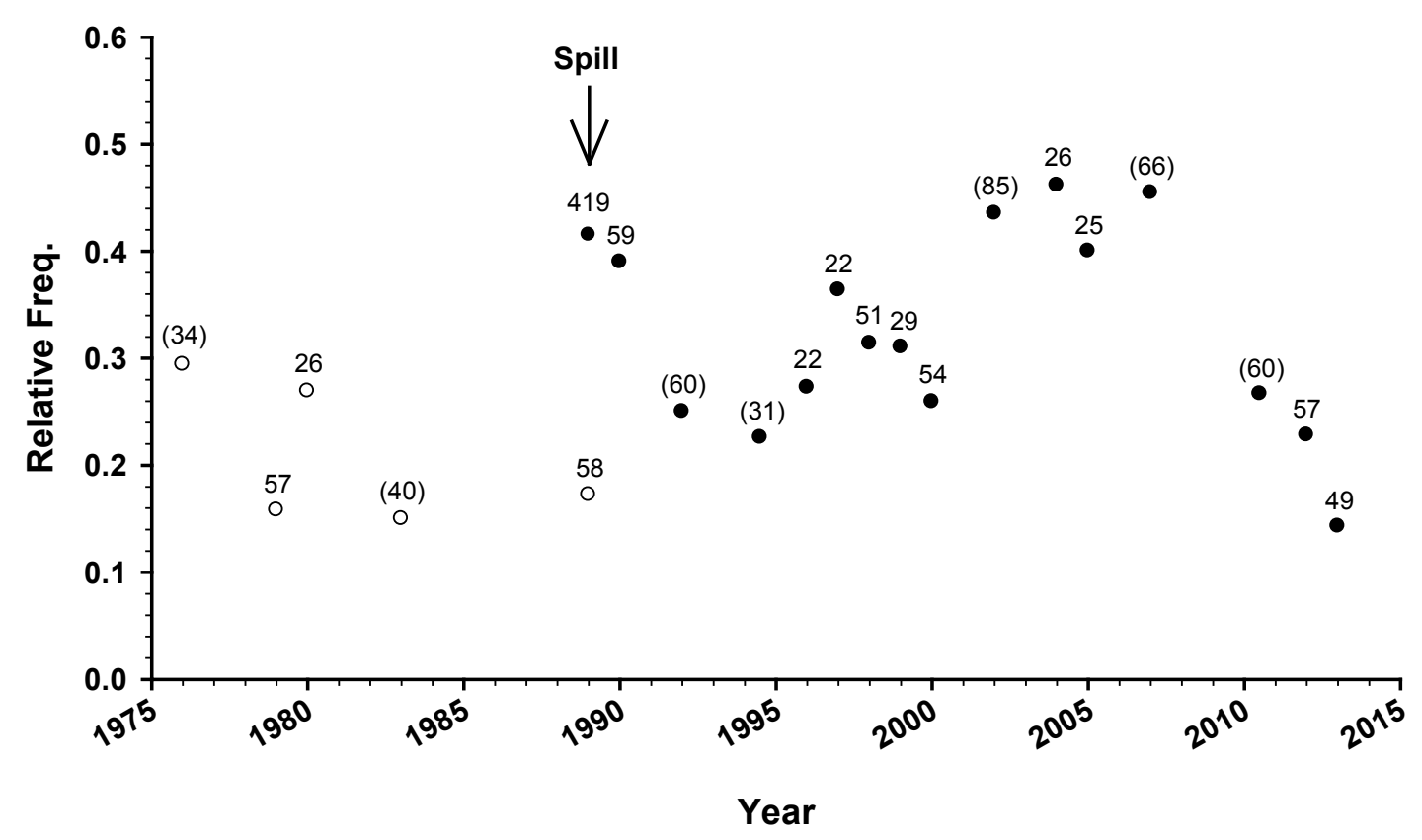

Figure 2.2. Relative proportion of prime-age animals (2-8 yr-olds) in age distributions of sea otter carcasses collected on western Prince William Sound beaches from 1976 to 2013. Open circles denote pre-spill collections and filled circles denote post-spill collections. Note: Carcasses recovered the year of the spill but deemed to be pre-spill deaths make up the 1989 pre-spill distribution, and carcasses recovered in 1989 after the spill and deemed to be spill-related deaths make up the 1989 post-spill distribution. Numbers above symbols indicate total $\mathrm{N}$ for each distribution, and numbers in parentheses signify multiyear collections combined to ensure equal to or greater than five individuals in each age-class.

\section{Discussion}

Survey data indicated increasing sea otter numbers in WPWS and at heavily oiled Knight Island, starting in about 2007 (Chapter 1, this report). However, survival models based on carcass collections did not predict improved survival rates through at least 2008 (Monson and others, 2011). In general, the proportion of prime-age animals in carcass collections had been increasing since the spill (fig. 2.2) while the proportion of older animals had been decreasing. In 2011, the proportion of prime-age animals decreased to pre-spill levels, and remained similar to pre-spill values in 2012 and 2013 (fig. 2.2). Thus, it appears that the elevated mortality described by Monson and others $(2000,2011)$ may have continued to affect at least some portion of the population until about 2010, with the combined 2010-2013 distribution representing a transition period in sea otter mortality to the pre-spill pattern. 
The observed increase in sea otter abundance at heavily oiled northern Knight Island began between 2005 and 2007 (Chapter 1, this report), and preceded the return of the age-atdeath distribution to the pre-spill pattern by four to six years. The lag between the increase in abundance and a return to a "normal" pre-spill age-at-death distribution may be explained by the time required for the standing population age-structure (that is, the distribution of ages of the living animals) to stabilize. Specifically, under normal conditions, the age-at-death distribution developed from a stable standing age-structure typical of a relatively long-lived species. However, during the period when survival rates were transitioning from post-spill rates to more normal rates, the standing age-structure of the population was shifting, and the age-at-death distributions reflected both the changing standing age-structure and the changing survival rates. As chronic exposure to lingering oil declined to a level where adverse effects on survival diminished, the living population began to increase in size. However, it took several years of relatively constant survival rates for the standing age-structure to re-stabilize, and allow the return of the age-at-death distribution to the normal pattern, dominated by juvenile and old-age classes.

Based on sea otter abundance data through 2013 (Chapter 1, this report) and return of the sea otter carcass age distributions to pre-spill proportions by 2013, exposure of pups and juveniles likely decreased to biologically insignificant levels by the early to mid-2000s, with the last of the affected cohorts dying out by the early 2010s. These findings are supported by the gene transcription data (Chapter 3, this report), which suggest that effects of exposure persisted through 2008 but declined by 2012. It appears that for all ages, survival consequences of exposure have abated over the past few years and the WPWS sea otter population no longer is limited to any demographically meaningful degree by oil exposure. 


\title{
Chapter 3. Gene Transcript Profiles in Sea Otters from Prince William Sound, Alaska, 2008 and 2012, and Clinically Normal and Wild Reference Sea Otters
}

\author{
By L. Bowen, A.K. Miles, B.E. Ballachey, and J.L. Bodkin
}

\section{Introduction}

To assess recovery of sea otters from the 1989 Exxon Valdez oil spill, the Exxon Valdez Oil Spill Trustee Council established demographic and biochemical criteria. To examine the biochemical status of the sea otters in the oiled area of western Prince William Sound (WPWS), we used gene transcription studies. Exposure to petroleum hydrocarbons has the potential to cause not only catastrophic short-term effects, but also important but often underappreciated long-term damage to individuals, populations, and ecosystems. The question of extent and duration of long-term effects is difficult to answer, as the pathophysiological changes within an individual may be significant yet subtle, and consequently undetectable using classical diagnostic methods. The earliest observable signs of health impairment are altered levels of gene transcripts, evident prior to clinical manifestation (McLoughlin and others, 2006). As a result of this keystone function, analysis of mRNA can provide information about dynamic changes in the functional state of an organism. The utility of the methodology used in our study relies on the assumption that oil-induced pathology in sea otters is accompanied by predictable and specific changes in gene transcription.

In 2008, we sampled sea otters in oiled and unoiled areas of WPWS and compared them to captive and wild reference otters from the Alaska Peninsula. We concluded that sea otters in oiled areas had gene transcription patterns consistent with chronic, low-grade exposure to organic compounds (Miles and others, 2012). In 2012, we resampled sea otters in the same areas of WPWS to evaluate whether gene transcription patterns observed in 2008 persisted. Here, we provide results of gene transcription analyses on sea otters sampled in the summer of 2012, and compare these findings to those from 2008.

\section{Methods}

\section{Free-Ranging Target Sea Otters}

Forty-five sea otters from three different areas of WPWS were captured in summer 2008 and 60 sea otters were captured in 2012. Sea otters were captured at Knight Island (heavily oiled; $\mathrm{n}=16,2008 ; \mathrm{n}=24,2012$ ), Prince of Wales Passage (moderate level of oil contamination; $n=15$, 2008; $n=18,2012$ ), and Montague Island (unoiled, reference area; $n=14,2008 ; n=18,2012$ ) (fig. 1, "Introduction"). Lingering oil from the EVOS was more prevalent at Knight Island than at Prince of Wales Passage at least through 2002 (Short and others, 2004). Sea otters were captured and blood drawn within 1-2 hours. All target as well as captive and free-ranging reference sea otters were anesthetized with fentanyl citrate and midazolam hydrochloride (Monson and others, 2001) prior to blood draw. Capture methods are presented in greater detail in Miles and others (2012) and Bodkin and others (2012). 


\section{Captive and Free-Ranging Reference Sea Otters}

Blood samples from 17 captive reference sea otters were obtained from the Monterey Bay Aquarium (Monterey, Calif.), Shedd Aquarium (Chicago, Ill.), Oregon Coast Aquarium (Newport, Oreg.), and the Vancouver Aquarium (Vancouver, B.C.) in 2008, 2009, and 2010, and included both northern and southern subspecies (Bowen and others, 2011). These animals were identified as clinically normal by staff veterinarians at these aquaria at the time of blood collection.

Wild reference sea otters were captured along the southwestern Alaska Peninsula in summer 2009, and 25 of these sea otters used in our study were deemed clinically normal by the attending veterinarian. Alaska Peninsula sea otters were included as reference because they were from an area not affected by the EVOS, far removed from any known human perturbations, and were at or below equilibrium density. These sea otters were captured and processed the same as the WPWS sea otters.

\section{Blood Collection and RNA Extraction}

A $2.5 \mathrm{~mL}$ sample from each sea otter was drawn directly into a PAXgene ${ }^{\mathrm{TM}}$ blood RNA collection tube (PreAnalytiX ${ }^{\complement}$, Switzerland) from either the jugular or popliteal vein and then frozen at $-20^{\circ} \mathrm{C}$ until extraction of RNA (Bowen and others, 2011). The PAXgene ${ }^{\mathrm{TM}}$ tube contains RNA stabilizing reagents that protect RNA molecules from degradation by RNases and prevents further induction of gene transcription. Without stabilization, copy numbers of individual mRNA species in whole blood can change more than 1,000-fold during storage and transport. The RNA from blood in PAXgene ${ }^{\mathrm{TM}}$ tubes was isolated according to manufacturer's standard protocols (Bowen and others, 2007, 2011; Miles and others, 2012). All RNA was checked for quality by running on both an agarose gel and on a nanodrop 2000 and achieved A260/A280 ratios of approximately 2.0 and A260/A230 ratios of less than 1.0. A standard cDNA synthesis was performed on $2 \mu \mathrm{g}$ of RNA template from each animal (Bowen and others, 2007, 2012; Miles and others, 2012). Real-time PCR systems for the individual, sea otter-specific reference or housekeeping gene (S9) and genes of interest were run in separate wells (Bowen and others, 2007, 2011; Miles and others, 2012; table 1). Amplifications were conducted on a 7300 Real-time Thermal Cycler (Applied Biosystems ${ }^{\mathrm{TM}}$, Foster City, Calif.) with reaction conditions identical to those in Bowen and others $(2007,2011)$ and Miles and others (2012).

\section{Statistical Analysis}

We used nonparametric statistical analyses because the cycle threshold $\left(\mathrm{C}_{\mathrm{T}}\right)$ measure of gene transcription provided by qPCR may have a lognormal distribution (McLoughlin and others, 2006). We used ANOSIM (Primer v6 software, Plymouth, U.K.) nonparametric analysis of variance to test for differences in gene transcription among locations, that is, the WPWS subpopulations and reference sea otters (Alaska Peninsula and captive), and between years. We used conventional nonparametric mean comparison tests (Kruskal-Wallis with Dunns' Multiple Comparison; $\mathrm{NCSS}^{\odot}$ Statistical Software, 2007, Kaysville, Utah) to evaluate transcript values of each gene by classification groups (that is, location [including reference] and year). 
We conducted multivariate, multidimensional scaling analysis (MDS) in conjunction with cluster analysis of individual sea otters clustered by similarity in transcription and not by predefined groups such as location in order to facilitate comparison to Miles and others (2012). Statistical comparisons of clusters were made using SIMPROF (Primer v6). Statistical significance was based on $p$ values $<0.05$, and in the case of the ANOSIM tests, relative to the $\mathrm{R}$ statistic value.

\section{Results}

Overall gene transcription $\left(\mathrm{C}_{\mathrm{T}}\right)$ values differed between sea otters from WPWS in 2008 or 2012 and the Alaska Peninsula or captive sea otters (ANOSIM, $p<0.001$, Global $\mathrm{R}=0.46$, with 0 permuted statistics $>$ Global R) (fig. 3.1). The Alaska Peninsula and captive sea otters did not differ $(p=0.46)$ and hereafter "reference" refers to these two groups collectively. Individually, the three 2008 WPWS subpopulations differed significantly $(p<0.001)$ from the reference sea otters, with indication of less chance of overlap in transcription profiles with Knight Island $(\mathrm{R}=0.40$ [Alaska Peninsula], 0.53 [captives]) than with Montague Island $(\mathrm{R}=0.25,0.28)$ or Prince of Wales Passage $(\mathrm{R}=0.28,0.21)$ sea otters. Transcription profiles did not differ significantly within the three 2008 subpopulations $(p>0.16)$.

The three 2012 WPWS subpopulations differed significantly $(p<0.001)$ from the reference sea otters. There was less chance of overlap in transcription profiles with sea otters from moderately oiled Prince of Wales Passage $(\mathrm{R}=0.71,0.85)$ than with those from oiled Knight Island $(\mathrm{R}=0.64,0.75)$ or unoiled Montague Island $(\mathrm{R}=0.65,0.83)$ (fig. 3.1). Transcription profiles did not differ significantly among the three 2012 WPWS subpopulations $(p>0.42)$.All 2012 WPWS subpopulations differed significantly from all 2008 WPWS subpopulations $(p<0.001)$, with an overall pattern of lower levels of gene transcription ("down-regulation" of genes) noted in 2012 (fig. 3.2).

Using Kruskal-Wallis, 11 of 13 genes were identified that had significant differences between at least two classification groups (fig. 3.2). Most evident, HDC, THRB, HSP70, IL10, MX1, and CaM differed between 2008 and 2012 otters regardless of location, with higher levels of gene transcription in 2008 than in 2012. Although not statistically significant, HDC (associated with tumor-formation) was more highly transcribed at Knight Island than at Montague Island or Prince of Wales Passage in 2008 (fig. 3.1), but this finding did not persist in 2012. There were minimal differences in transcription levels for COX2, AHR, IL18, DRB, and 5HTT between 2008 and 2012. Transcription of CYT and CCR3 did not differ among classification groups.

Patterns depicted by the MDS analyses were similar to that reported in Miles and others (2012), with differences attributable to the inclusion of the 2012 samples (fig. 3.2). More 2008 sea otters from Knight Island were found in Clusters 1, 1a, and 1b than those from Prince of Wales Passage or Montague Island, and these clusters included no sea otters from 2012. Cluster 2 included all captive and most (76 percent) Alaska Peninsula sea otters. Cluster 1 was characterized in particular by higher levels of transcription of HDC, CYT, and HSP70. Importantly, the 2008 and 2012 samples were distinctly separate; Cluster 3 contained mostly 2012 sea otters (regardless of location), attributed primarily to lower levels of gene transcription. 


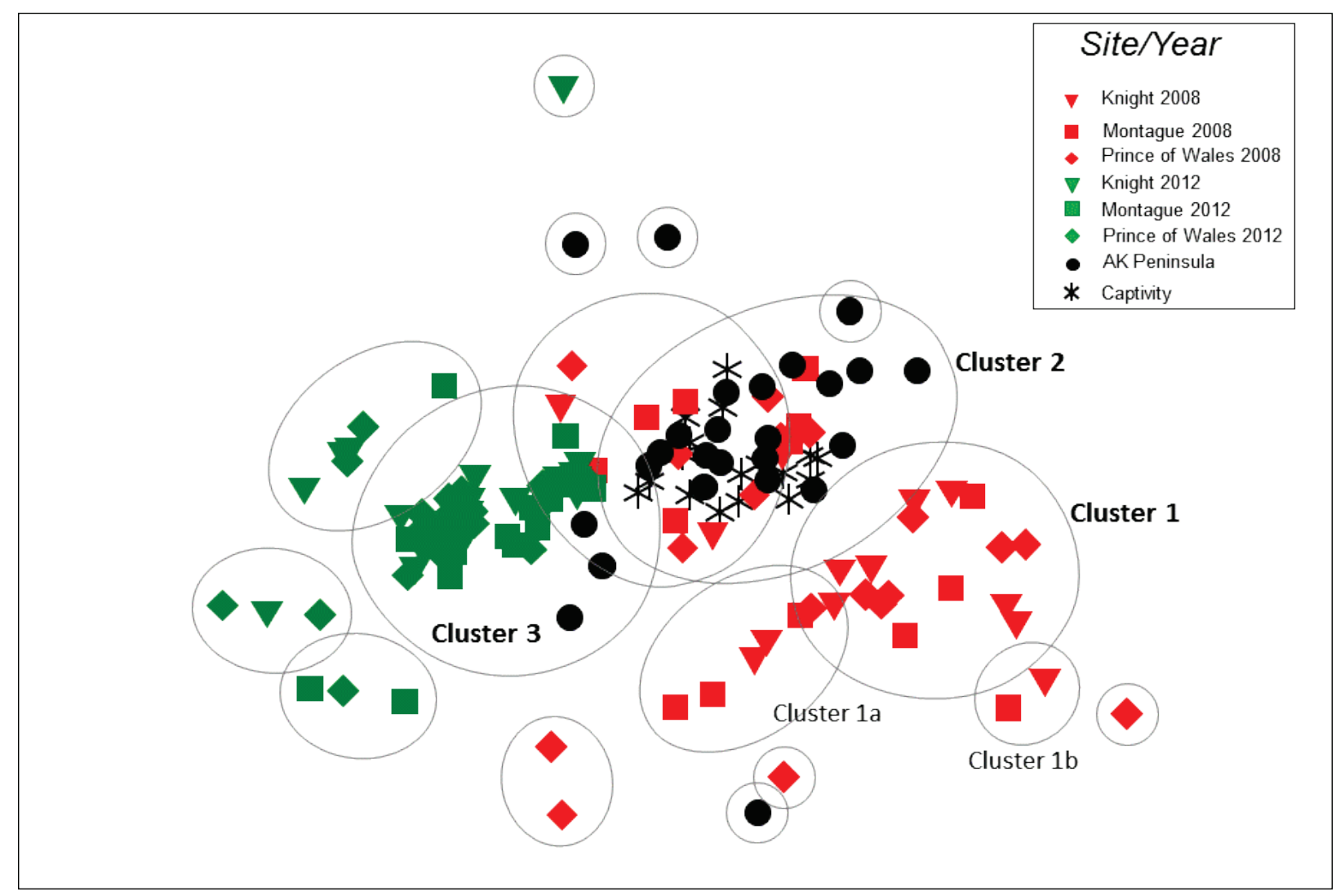

Figure 3.1. Multivariate, nonparametric, multidimensional scaling of gene transcription profiles (see table 3.1 for description of genes) of sea otters sampled at three locations in western Prince William Sound, Alaska, 2008 and 2012, the Alaska Peninsula, and in captivity at aquaria. Interpretive cluster analysis and SIMPROF (similarity profile permutation test; Primer, v6, Plymouth, U.K.) indicated significant $(p<0.001-$ 0.05 ) separation among all clusters depicted by circles. The figure is two-dimensional (Stress $=0.11$ ), however, three-dimensional (Stress $=0.08$ ) representation depicted further separation among clusters in 3-D space. 

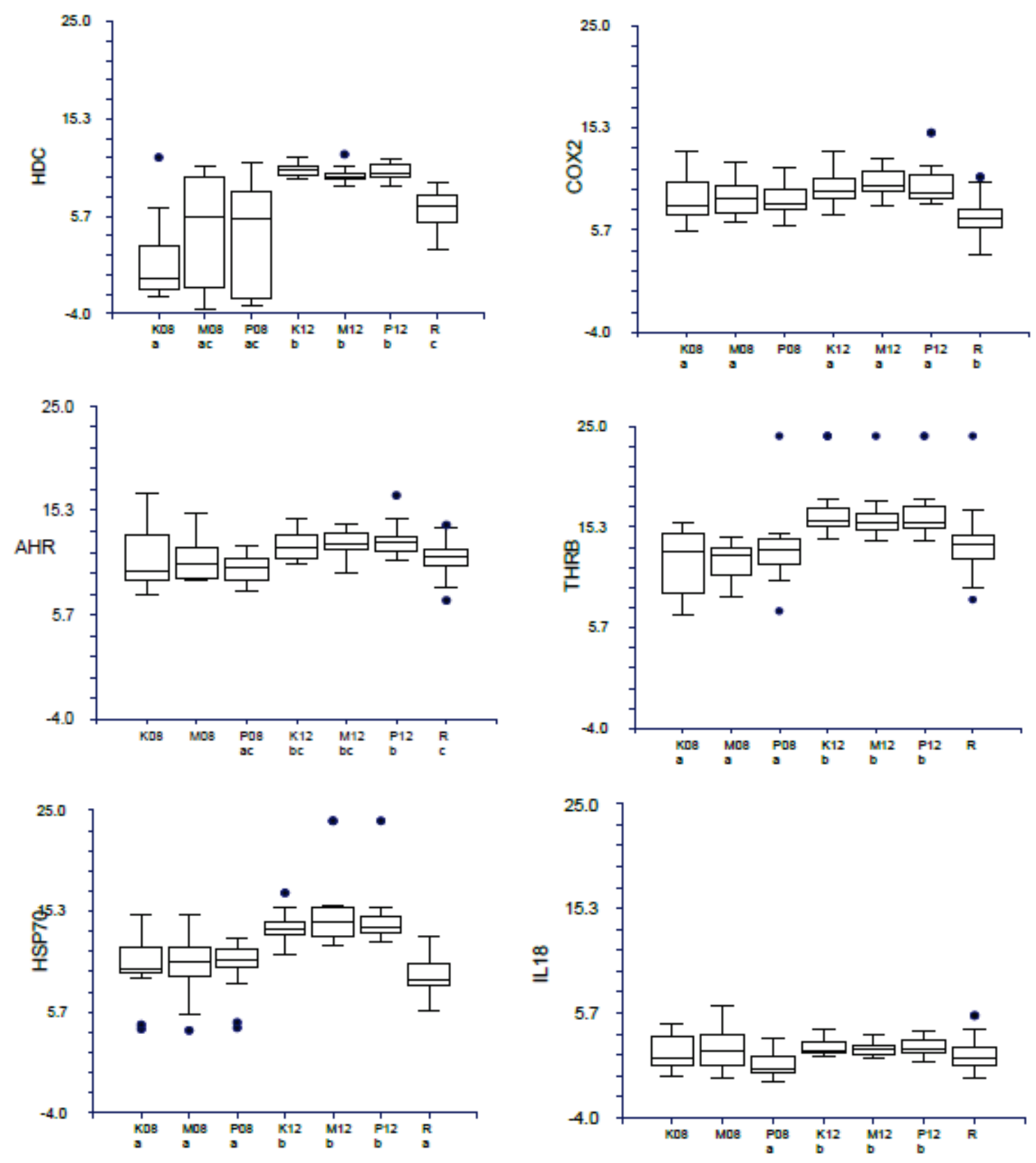

Figure 3.2. Distribution of average cycle threshold (CT) values across genes targeted by the panel of 13 primer sets. Bars range from the 10th to the 90 th percentile of values for each gene, normalized to the $S 9$ housekeeping gene for each sea otter. Circles represent 5 th and 95 th percentile outliers. Indicated are those genes that differed significantly among sea otters by classification groups (location and year), using Kruskal-Wallis and Dunns' Multiple Comparison Tests. K, Knight Island; M, Montague Island; P, Prince of Wales Passage; R, Reference; 08, 2008; 12, 2012. Classification groups with like letters (a, b, or c) do not differ significantly; no letter, does not differ from any comparisons. 

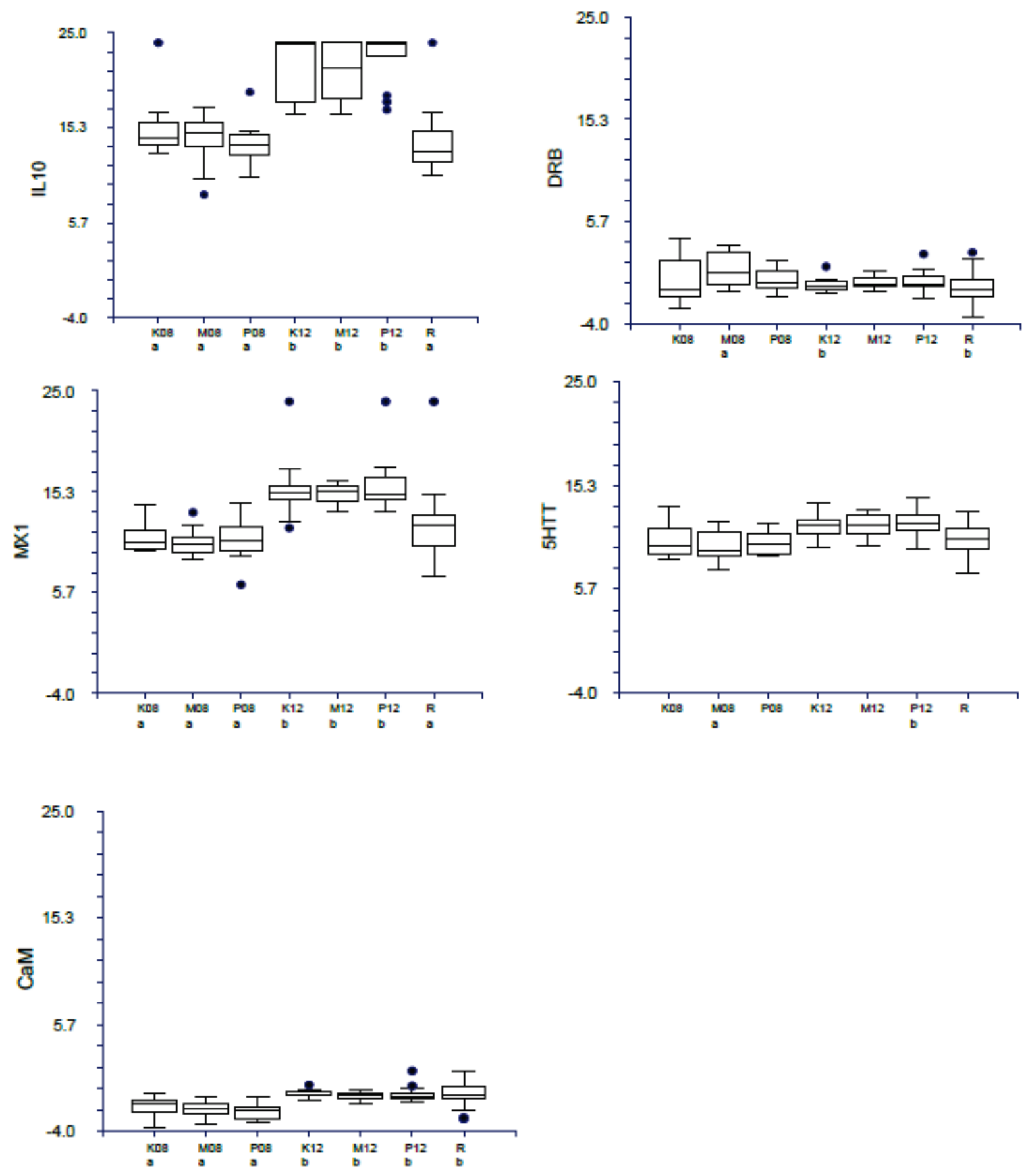

Figure 3.2.-Continued. 


\section{Discussion}

Gene transcription patterns in the 2008 WPWS sea otters, particularly those from Knight Island, generally were suggestive of molecular reactions to organic exposure, tumor formation, inflammation, and viral infection that may be consistent with chronic, low-grade exposure to an organic substance (Miles and others, 2012). This is consistent with findings from Bodkin and others (2012), which document a potential pathway of exposure to lingering oil for sea otters foraging in the intertidal where lingering oil persisted. In particular, sea otters from the spill area demonstrated elevated transcription of several of the genes measured, including HDC and THR, and lower transcription, or down-regulation, of DRB. Dong and others (1997) reported downregulation of DRB by a dioxin compound, and both polycyclic aromatic hydrocarbons (constituents of crude oil) and dioxin-like compounds have been implicated in similar biochemical detoxification responses.

In contrast, the 2012 WPWS sea otters had an overall pattern of down-regulation of gene transcription. In general, the regulation of gene transcription includes mechanisms to increase or decrease the production of mRNA, and the occurrence of low gene transcription has been observed in other marine mammal studies (Stott and McBain, 2012). However, the prevalence of down-regulation among 2012 WPWS sea otters was noteworthy and contributing factors are not fully understood. We confirmed that the observed low transcription values were not a result of a laboratory artifact. We analyzed all samples in duplicate, and if any duplicate samples were greater than $1 \mathrm{C}_{\mathrm{T}}$ difference, they were re-analyzed. All samples were run with an internal reference standard (the S9 housekeeping gene). If the internal reference was greater than $3 \mathrm{C}_{\mathrm{T}}$ values from the average internal reference value for control populations, the entire panel was rerun in duplicate; this always resulted from insufficient RNA and those samples were omitted from analysis (that is, $<1$ percent of the samples). Finally, samples were run with other samples from other Alaska and also California populations and re-run in different combinations to check for 'plate' or 'batch' effects; no such effects were encountered. Of significance, we conducted analyses of sea otters from California during the same time period as analyses of the 2012 WPWS sea otters. About 50 percent of the California otters analyzed aligned with the reference group, about 10 percent displayed high transcription, and about 40 percent had low transcription of 3-6 of 13 genes. Most of these low transcription animals were from a specific area of the California coastline. Causes of down-regulation of gene transcription in WPWS in 2012 are not certain, and should be a topic of continued research.

We found no evidence that gene transcription in sea otters captured in WPWS in 2012 differed by oiling history, including genes that indicated potential responses to organic compounds in 2008. We conclude that these findings indicate that conditions specific to effects of exposure to oil characterized by our suite of genes improved between 2008 and 2012. We caution that the implications of overall low transcription observed in 2012, in terms of interpretation of potential exposure to oil, are not certain. We note that the timing of convergence of patterns of transcription of potentially exposure-related genes in our suite across different oiling histories in 2012 relative to 2008 is consistent with improvements in survival (Chapter 2) and increasing population trajectories (Chapter 1) during that same period. 
Table 3.1. Function of 13 genes identified in free-ranging sea otters sampled in western Prince William Sound, Alaska, in 2008 and 2012, and Alaska Peninsula in 2009, and in clinically normal captive sea otters sampled in 2008, 2009, or 2010.

\begin{tabular}{cl}
\hline Gene & \multicolumn{1}{c}{ Gene function } \\
\hline HDC & $\begin{array}{l}\text { The HDCMB21P gene codes for a translationally controlled tumor protein (TCTP) implicated } \\
\text { in cell growth, cell cycle progression, malignant transformation, tumor progression, and in the } \\
\text { protection of cells against various stress conditions and apoptosis (Bommer and Thiele, }\end{array}$ \\
2004;Tuynder and others, 2004; Ma and others, 2010). Up-regulation of HDC is indicative of \\
the development or existence of cancer. Environmental triggers may be responsible for \\
population-based, up-regulation of HDC. HDC transcription is known to increase with \\
exposure to carcinogenic compounds such as polycyclic aromatic hydrocarbons (Bowen and \\
others, 2007; Raisuddin and others, 2007; Zheng and others, 2008).
\end{tabular}

COX2 Cyclooxygenase-2 catalyzes the production of prostaglandins that are responsible for promoting inflammation (Goldsby and others, 2003). Cox2 is responsible for the conversion of arachidonic acid to prostaglandin $\mathrm{H} 2$, a lipoprotein critical to the promotion of inflammation (Harris and others, 2002). Up-regulation of Cox2 is indicative of cellular or tissue damage and an associated inflammatory response.

CYT The complement cytolysis inhibitor protects against cell death (Jenne and Tschopp, 1989). Up-regulation of CYT is indicative of cell or tissue death.

AHR The arylhydrocarbon receptor responds to classes of environmental toxicants including polycyclic aromatic hydrocarbons, polyhalogenated hydrocarbons, dibenzofurans, and dioxin (Oesch-Bartlomowicz and others, 2005). Depending upon the ligand, AHR signaling can modulate $T$-regulatory $\left(\mathrm{T}_{\mathrm{REG}}\right)$ (immune-suppressive) or T-helper type $17\left(\mathrm{~T}_{\mathrm{H}} 17\right)$ (proinflammatory) immunologic activity (Quintana and others, 2008; Veldhoen and others, 2008).

THR The thyroid hormone receptor beta can be used as a mechanistically based means of characterizing the thyroid-toxic potential of complex contaminant mixtures (Tabuchi and others, 2006). Thus, increases in THR transcription may indicate exposure to organic compounds including PCBs and associated potential health effects, such as developmental abnormalities and neurotoxicity (Tabuchi and others, 2006). Hormone-activated transcription factors bind DNA in the absence of hormone, usually leading to transcriptional repression (Tsai and O’Malley, 1994).

HSP 70 The heat shock protein 70 is produced in response to thermal or other stress (Iwama and others, 1999; Tsan and Gao, 2004). In addition to being expressed in response to a wide array of stressors (including hyperthermia, oxygen radicals, heavy metals, and ethanol), heat shock proteins act as molecular chaperones (De Maio, 1999). For example, heat shock proteins aid the transport of the AHR/toxin complex in the initiation of detoxification (Tanabe and others, 1994).

IL-18 Interleukin-18 is a pro-inflammatory cytokine (Goldsby and others, 2003) and plays an important role in inflammation and host defense against microbes (Krumm and others, 2008). 
Table 3.1. Function of 13 genes identified in free-ranging sea otters sampled in western Prince William Sound, Alaska, in 2008 and 2012, and Alaska Peninsula in 2009, and in clinically normal captive sea otters sampled in 2008, 2009, or 2010.-Continued

\begin{tabular}{|c|c|}
\hline Gene & Gene function \\
\hline IL-10 & $\begin{array}{l}\text { Interleukin-10 is an anti-inflammatory cytokine (Goldsby and others, 2003). Levels of IL-10 } \\
\text { have been correlated with relative health of free-ranging harbor porpoises, for example, } \\
\text { increased amounts of IL-10 correlated with chronic disease whereas the cytokine was } \\
\text { relatively reduced in apparently fit animals experiencing acute disease (Beineke and others, } \\
\text { 2007). Association of IL-10 transcription with chronic disease also has been documented in } \\
\text { humans (Rigopoulou and others, 2005). }\end{array}$ \\
\hline DRB & $\begin{array}{l}\text { A component of the major histocompatibility complex, the DRB class II gene, is responsible } \\
\text { for the binding and presentation of processed antigen to } \mathrm{T}_{\mathrm{H}} \text { lymphocytes, thereby facilitating } \\
\text { the initiation of an immune response (Goldsby and others, 2003; Bowen and others, 2006). } \\
\text { Up-regulation of MHC genes has been positively correlated with parasite load (Wegner and } \\
\text { others, 2006), whereas down-regulation of MHC has been associated with contaminant } \\
\text { exposure (Dong and others, 1997). }\end{array}$ \\
\hline Mx1 & $\begin{array}{l}\text { The Mx1 gene responds to viral infection (Tumpey and others, 2007). Vertebrates have an } \\
\text { early strong innate immune response against viral infection, characterized by the induction } \\
\text { and secretion of cytokines that mediate an antiviral state, leading to the up-regulation of the } \\
\text { MX-1gene (Kibenge and others, 2005). }\end{array}$ \\
\hline CCR3 & $\begin{array}{l}\text { The chemokine receptor } 3 \text { binds at least seven different chemokines and is expressed on } \\
\text { eosinophils, mast cells (MC), and a subset of Th cells (Th2) that generate cytokines } \\
\text { implicated in mucosal immune responses (Gurish and others, 2002; Kringel and others, 2006). } \\
\text { Up-regulation of CCR3 occurs in the presence of parasites (Gurish and others, 2002; Kringel } \\
\text { and others, 2006). }\end{array}$ \\
\hline $5 \mathrm{HTT}$ & $\begin{array}{l}\text { The serotonin transport gene codes for an integral membrane protein that transports the } \\
\text { neurotransmitter serotonin from synaptic spaces into presynaptic neurons. This transport of } \\
\text { serotonin by the SERT protein terminates the action of serotonin and recycles it in a sodium- } \\
\text { dependent manner (Jennings and others, 2006; Squire and others, 2008). Increased } \\
\text { transcription of 5HTT confers a low anxiety phenotype (Jennings and others, 2006). }\end{array}$ \\
\hline $\mathrm{CaM}$ & $\begin{array}{l}\text { Calmodulin }(\mathrm{CaM}) \text { is a small acidic } \mathrm{Ca}^{2+} \text {-binding protein, with a structure and function that is } \\
\text { highly conserved in all eukaryotes. CaM activates various } \mathrm{Ca}^{2+} \text {-dependent enzyme reactions, } \\
\text { thereby modulating a wide range of cellular events, including metabolism control, muscle } \\
\text { contraction, exocytosis of hormones and neurotransmitters, and cell division and } \\
\text { differentiation (Chen and others, } 2012) \text {. CaM also has been reported to be a pivotal calcium } \\
\text { metabolism regulator in shell formation ( } \mathrm{Li} \text { and others, 2004). }\end{array}$ \\
\hline
\end{tabular}




\section{Synthesis and Conclusions}

In this report, we present the latest findings from post-spill studies on sea otters that have been ongoing for more than two decades. The Exxon Valdez Oil Spill Trustee Council (EVOSTC) defined recovery for sea otters as the point in time when abundance of sea otters in oiled areas returns to level that would have existed had the spill not occurred, and there is no evidence of continuing exposure to lingering oil in the environment. In our summaries of data available through 2009 (Bodkin and others, 2011, 2012; Miles and others, 2012) for sea otters in areas of western Prince William Sound (WPWS) that received heavy shoreline oiling in 1989, these conditions had not been met, although there were indications that recovery was underway based on increasing numbers of sea otters at Knight Island. Further, demographic models based on ages-at-death and abundance data through 2008 (Monson and others, 2011) suggested that depressed survival of sea otters in heavily oiled areas continued to constrain recovery. Here, we integrate the results through 2013 and find our most recent data are consistent with the EVOSTC definition of recovery for sea otters.

Aerial surveys of abundance (Chapter 1) are a main component of our studies to evaluate status of recovery. By 2013, at the broader scale of WPWS, the estimated number of sea otters had more than doubled relative to the 1993 estimate (4,277 versus 2,054, respectively), and the increase over that time frame was greater than or similar to estimates of sea otters that died within the first year of the spill, indicating that the demographic metric of the recovery definition had been met. For the region of northern Knight Island, which received heavy oiling of shorelines in 1989 and consequently was anticipated to be an area where recovery would be slowest, abundance was depressed for almost two decades relative to the pre-spill estimate. By 2011, the number of sea otters at Knight Island was similar to estimated pre-spill numbers, and similar levels of abundance continued through 2012 and 2013. Thus, based solely on abundance estimates, the sea otter population in WPWS in 2013 had grown to a number consistent with the definition of recovery.

The most recent data on ages-at-death of sea otters in WPWS (Chapter 2) provide additional findings consistent with recovery of the population. Annual carcass collections were initiated in WPWS in the 1970s, so the ages-at-death data provide a solid empirical baseline for evaluating recovery from the spill. Pre-spill data indicate that mortality of sea otters typically was comprised largely of very young and older sea otters, with relatively few prime age (defined here as 2-8-year olds) otters dying each year. This pattern was altered after the spill when, for about two decades, annual carcass collections showed a relatively high proportion of prime-age otters dying each year. Starting in 2011, we observed a distinct change in the age-class proportions of dying sea otters, with a return to the pre-spill pattern of predominantly young and older sea otters recovered as carcasses. This pattern continued in 2012 and 2013, which we interpret as evidence that over the past few years, chronic exposure to lingering oil and/or chronic effects due to previous exposure have abated to the point where they are no longer factors constraining survival. A higher proportion of sea otters in oiled areas are again surviving to older ages, as documented in WPWS prior to the spill. 
To assess continuing exposure to lingering oil, we have utilized gene transcription assays, monitoring an array of 13 genes selected based on studies of mink exposed to oil (Bowen and others, 2007). Results from sea otters sampled in WPWS in 2008 were consistent with ongoing exposure to organic compounds (Miles and others, 2012), and in concert with other data, we interpreted the gene transcription data to suggest continuing chronic exposure to oil from the 1989 spill. Sea otters were resampled in 2012 for gene transcription (Chapter 3), and gene transcription values from 2012 differed from 2008, as well as from the two reference groups (captive and Alaska Peninsula sea otters) used for comparison to the 2008 samples (Miles and others, 2012). In contrast to previous data, the 2012 samples indicated low levels of gene expression for all otters sampled in WPWS (that is, in both oiled and unoiled areas). This result was not expected, and is difficult to interpret without data from a wider panel of genes. However, the low transcription levels for genes that previously showed elevated levels, and lack of difference in transcription rates between otters from heavily, moderately, and unoiled areas of WPWS suggest that sea otters were not exposed to oil in 2012.

Overall, we conclude that current population level data for sea otters in WPWS are consistent with the EVOSTC definition of recovery for sea otters from the long-term injury incurred in the wake of the 1989 oil spill. The support for this is based primarily on demographic data, including (1) a return to estimated pre-spill abundance of sea otters at northern Knight Island, a heavily oiled area within WPWS, and (2) a return to pre-spill mortality patterns based on ages-at-death. Gene transcription rates in 2012 were similar in sea otters from oiled, moderately oiled and unoiled areas, suggesting abatement of exposure effects in 2012. However, because 2012 gene transcription rates generally were low for sea otters from all areas relative to 2008 , we cannot fully interpret these observations without data from a wider panel of genes. This slight uncertainty with respect to the data from the biochemical indicator is outweighed by the strength of the data for the demographic indicators. The return to pre-spill numbers and mortality patterns suggests a gradual dissipation of lingering oil over the past two decades, to the point where continuing exposure is no longer of biological significance to the WPWS sea otter population. 


\section{References Cited}

Ballachey, B.E., Bodkin, J.L., and DeGange, A.R., 1994, An overview of sea otter studies, in Loughlin, T.R., ed., Marine mammals and the Exxon Valdez: San Diego, Academic Press, p. 47-59.

Ballachey, B.E., Bodkin, J.L., Howlin, S., Doroff, A.M., and Rebar, A.H., 2003, Correlates to survival of juvenile sea otters in Prince William Sound, Alaska: Canadian Journal of Zoology, v. 81, p. 1494-1510.

Beineke, A., Siebert, U., Muller, G., and Baumgartner, W., 2007, Increased blood interleukin-10 mRNA levels in diseased free-ranging harbor porpoises (Phocoena phocoena): Veterinary Immunology and Immunopathology, v. 115, p. 100-106.

Bodkin, J.L., Ames, J.A., Jameson, R.J., Johnson, A.M., and Matson, G.M., 1997, Estimating age of sea otters with cementum layers in the first premolar: Journal Wildlife Management, v. 61, p. 967-973.

Bodkin, J.L., Ballachey, B.E., Coletti, H.A., Esslinger, G.G., Kloecker, K.A., Rice, S.D., Reed, J.A., and Monson, D.H., 2012, Long-term effects of the Exxon Valdez oil spill-Sea otter foraging in the intertidal as a pathway of exposure to lingering oil: Marine Ecology Progress Series, v. 447, p. 273-287, doi: 10.3354/meps09523.

Bodkin, J.L., Ballachey, B.E., Dean, T.A., Fukuyama, A.K., Jewett, S.C., McDonald, L., Monson, D.H., O'Clair, C.E., and VanBlaricom, G.R., 2002, Sea otter population status and the process of recovery from the 1989 'Exxon Valdez' oil spill: Marine Ecology Progress Series, v. 241, p. 237-253

Bodkin, J.L., Ballachey, B.E., and Esslinger, G.G., 2011, Trends in sea otter population abundance in western Prince William Sound, Alaska: Progress toward recovery following the 1989 Exxon Valdez oil spill: U.S. Geological Survey Scientific Investigations Report 20115213, 14 p.

Bodkin, J.L., Burdin, A.M., and Ryazanov, D.A., 2000, Age- and sex-specific mortality and population structure in sea otters: Marine Mammal Science, v. 16, no. 1, p. 201-219.

Bodkin, J.L., and Jameson, R.J., 1991, Patterns of seabird and marine mammal carcass deposition along the central California coast, 1980-1986: Canadian Journal of Zoology, v. 69, p. 1149-1155.

Bodkin, J.L., and Udevitz, M.S., 1999, An aerial survey method to estimate sea otter abundance, in Garner, G.W., and others, eds., Marine Mammal Survey and Assessment Methods: Rotterdam, Netherlands, Balkema Press, p. 13-26.

Bommer, U.A., and Thiele, B.J., 2004, The translationally controlled tumour protein (TCTP): International Journal of Biochemistry and Cell Biology, v. 36, p. 379-385.

Boufadel, M.C., Sharifi, Y., Van Aken, B., Wrenn, B.A., and Lee, K., 2010, Nutrient and oxygen concentrations within the sediments of an Alaskan beach polluted with the Exxon Valdez Oil Spill: Environmental Science \& Technology, v. 44, p. 7418-7424.

Bowen, L., Aldridge, B., Miles, A.K., and Stott, J.L., 2006, Expressed MHC class II genes in sea otters (Enhydra lutris) from geographically disparate populations: Tissue Antigens, v. 67, p. 402-408.

Bowen, L., Miles, A.K., Murray, M., Haulena, M., Tuttle, J., Van Bonn, W., Adams, L., Bodkin, J.L., Ballachey, B.E., Estes, J.A., Tinker, M.T., Keister, R., and Stott, J.L., 2011, Gene transcription in sea otters (Enhydra lutris); emerging diagnostics in marine mammal and ecosystem health: Molecular Ecology Resources, v. 12, p. 67-74. 
Bowen, L., Schwartz, J., Aldridge, B., Riva, F., Miles, A.K., Mohr, F.C., and Stott, J.L., 2007, Differential gene expression induced by exposure of captive mink to fuel oil-A model for the sea otter: EcoHealth, v. 4, p. 298-309.

Bowyer, R.T., Blundell, G.M., Ben-David, M., Jewett, S.C., Dean, T.A., and Duffy, L.K., 2003, Effects of the EXXON VALDEZ oil spill on river otters: Injury and recovery of a sentinel species: Wildlife Monographs, v. 153, p. 1-53.

Caughley, G., 1966, Mortality patterns in mammals: Ecology, v. 47, p. 906-918.

Chen, Z., Wang, H., Matsumura, K., and Qian, P., 2012, Expression of calmodulin and myosin light chain kinase during larval settlement of the barnacle Balanus amphitrite: PLoS ONE, 7:e31337, doi: 10.1371/journal.pone.0031337.

Costa, D.P., and Kooyman, G.L., 1982, Oxygen consumption, thermoregulation, and the effect of fur oiling and washing on the sea otter, Enhydra lutris: Canadian Journal of Zoology, v. 60, p. 2761-2767.

Dean, T.A., Bodkin, J.L., Fukuyama, A.K., Jewett, S.C., Monson, D.H., O’Clair, C.E., and VanBlaricom, G.R., 2002, Food limitation and the recovery of sea otters following the Exxon Valdez oil spill: Marine Ecology Progress Series, v. 241, p. 255-270.

Dean, T.A., Bodkin, J.L., Jewett, S.C., Monson, D.H., and Jung, D., 2000, Changes in sea urchins following a reduction in sea otter density as a result of the Exxon Valdez oil spill: Marine Ecology Progress Series, v. 199, p. 281-291.

De Maio, A., 1999, Heat shock proteins-Facts, thoughts, and dreams: Shock, v. 11, p. 1-12.

Dong, L., Ma, Q., and Whitlock, J.P., Jr., 1997, Down-regulation of major histocompatibility complex Q1b gene expression by 2,3,7,8-tetrachlorodibenzo-p-dioxin: Journal of Biological Chemistry, v. 272, p. 29614-29619.

Eberhardt, L.L., 1985, Assessing the dynamics of wild populations: Journal of Wildlife Management, v. 49, p. 997-1012.

Emlen, J.M., 1970, Age specificity and ecological theory: Ecology, v. 51, p. 588-601.

Esler, D., Ballachey, B.E., Trust, K.A., Iverson, S.A., and others, 2011, Cytochrome P4501A biomarker indication of the timeline of chronic exposure of Barrow's goldeneyes to residual Exxon Valdez oil: Marine Pollution Bulletin, v. 62, p. 609-614.

Esler, D., Bowman, T.D., Trust, K.A., Ballachey, B.E., and others, 2002, Harlequin duck population recovery following the Exxon Valdez oil spill: progress, process and constraints: Marine Ecology Progress Series, v. 241, p. 271-286.

Esler, D., Trust, K.A., Ballachey, B.E., Iverson, S.A., and others, 2010, Cytochrome P4501A biomarker indication of oil exposure in harlequin ducks up to 20 years after the Exxon Valdez oil spill: Environmental Toxicological Chemistry, v. 29, p. 1138-1145.

Exxon Valdez Oil Spill Trustee Council, 2010, Update, Injured Resources and Services: Website, accessed January 17, 2014, at http://www.evostc.state.ak.us/index.cfm?FA=status.injured.

Fukuyama, A.K., Shigenaka, G., and Hoff, R.Z., 2000, Effects of residual Exxon Valdez oil on intertidal Protothaca staminea-Mortality, growth, and bioaccumulation of hydrocarbons in transplanted clams: Marine Pollution Bulletin, v. 40, p. 1042-1050.

Galt, J.A., and Payton, D.L., 1990, Movement of oil spilled from the T/V Exxon Valdez, in Bayha, K., and Kormendy, J., eds., Sea otter symposium: Proceedings of a symposium to evaluate the response effort on behalf of sea otters after the $T / V$ Exxon Valdez oil spill into Prince William Sound, Anchorage, Alaska, April 17-19, 1990, U.S. Department of Interior Biological Report, 90(12). 
Garrott, R.A., Eberhardt, L.L., and Burn, D.M., 1993, Mortality of sea otters in Prince William Sound following the Exxon Valdez oil spill: Marine Mammal Science, v. 9, no. 4, p. 343-359. Garshelis, D.L., 1997, Sea otter mortality estimated from carcasses collected after the Exxon Valdez oil spill: Conservation Biology, v. 11, no. 4, p. 905-916.

Goldsby, R.A., Kindt, T.J., Osborne, B.A., and Kuby, J., 2003, Immunology, fifth edition: New York, W.H. Freeman and Company.

Golet, G.H., Seiser, P.E., McGuire, A.D., Roby, D.D., Fischer, J.B., and others, 2002, Long-term direct and indirect effects of the Exxon Valdez oil spill on pigeon guillemots in Prince William Sound, Alaska: Marine Ecology Progress Series, v. 241, p. 287-304.

Gurish, M.F., Humbles, A., Tao, H., Finkelstein, S., Boyce, J.A., Gerard, C., Friend, D.S., and Austen, K.F., 2002, CCR3 is required for tissue eosinophilia and larval cytotoxicity after infection with Trichinella spiralis: Journal of Immunology, v. 168, no. 11, p. 5730-5736.

Harris, S.G., Padilla, J., Koumas, L., Ray, D., and Phipps, R.P., 2002, Prostaglandins as modulators of immunity: Trends in Immunology, v. 23, p. 144-150.

Iwama, G.K., Mathilakath, M.V., Forsyth, R.B., and Ackerman, P.A., 1999, Heat shock proteins and physiological stress in fish: American Zoologist, v. 39, p. 901-909.

Jenne, D.E., and Tschopp, J., 1989, Molecular structure and functional characterization of a human complement cytolysis inhibitor found in blood and seminal plasma-Identity to sulfated glycoprotein 2, a constituent of rat testis fluid: Proceedings of the National Academy of Sciences, USA, v. 86, p.7123-7127.

Jennings, K.A., Loder, M.K., and Sheward, W.J., 2006, Increased expression of the 5-HT transporter confers a low-anxiety phenotype linked to decreased 5-HT transmission: Journal of Neuroscience, v.30, p. 8955-8964.

Jewett, S.C., Dean, T.A., Woodin, B.R., Hoberg, M.K., and Stegeman, J.J., 2002, Exposure to hydrocarbons ten years after the Exxon Valdez-Evidence from cytochrome P4501A expression and biliary FACs in nearshore demersal fishes: Marine Environmental Research, v. 54, p. 21-48.

Kenyon, K.W., 1969, The sea otter in the eastern Pacific Ocean: North American Fauna, v. 68, p. $1-352$.

Kibenge, M.J.T., Munir, K., and Kibenge, F.S.B., 2005, Constitutive expression of Atlantic salmon Mx1 protein in CHSE-214 cells confers resistance to infectious salmon Anaemia virus: Journal of Virology, v. 2, 75 p. 
Kringel, H., Iburg, T., Dawson, H., Aasted, B., and Roepstorff, A., 2006, A time course study of immunological responses in Trichuris suis infected pigs demonstrates induction of a local type 2 response associated with worm burden: International Journal for Parasitology, v. 36, p. 915924.

Krumm, B., Meng, X., Li, Y., Xiang, Y., and Deng, J., 2008, Structural basis for antagonism of humaninterleukin 18 by poxvirus interleukin 18-binding protein: Proceedings of the National Academy of Sciences, USA, v. 105, p. 20711-20715.

Li, H.L., and Boufadel, M.C., 2010, Long-term persistence of oil from the Exxon Valdez spill in two-layer beaches: Nature Geoscience, v. 3, p. 96-99.

Li, S., Xie, L., Zhang, C., Zhang, Y., and Gu, M., 2004, Cloning and expression of a pivotal calcium metabolism regulator-Calmodulin involved in shell formation from pearl oyster (Pinctada fucata) - Comparative biochemistry and physiology, part B: Biochemistry and Molecular Biology, v. 138, p. 235-243.

Ma Q., Geng, Y., Xu, W., Wu, Y., He, F., Shu, W., Huang, M., Du, H., and Li, M., 2010, The role of translationally controlled tumor protein in tumor growth and metastasis of colon adenocarcinoma cells: Journal of Proteome Research, v. 9, p. 40-49.

McLoughlin, K., Turteltaub, K., Bankaitis-Davis, D., Gerren, R., Siconolfi, L., Storm, K., Cheronis, J., Trollinger, D., Macejak, D., Tryon, V., and Bevilacqua, M., 2006, Limited dynamic range of immune response gene expression observed in healthy blood donors using RT-PCR: Journal of Molecular Medicine, v. 12, p. 185-195.

Miles, A.K., Bowen, L., Ballachey, B.E., Bodkin, J.L., and others, 2012, Variation in transcript profiles in sea otters (Enhydra lutris) from Prince William Sound, Alaska and clinically normal reference otters: Marine Ecology Progress Series, v. 451, p. 201-212.

Monnett, C., and Rotterman, L.M., 1995, Movements of weanling and adult female sea otters in Prince William Sound, Alaska, after the T/V Exxon Valdez oil spill: U.S. Fish and Wildlife Service, Exxon Valdez Oil Spill State/Federal Natural Resource Damage Assessment Final Report, Marine Mammal Study 6-12.

Monson, D.H., Doak, D.F., Ballachey, B.E., and Bodkin, J.L., 2011, Effect of the Exxon Valdez oil spill on the sea otter population of Prince William Sound, Alaska-Do lingering oil and source-sink dynamics explain the long-term population trajectory?: Ecological Applications, v. 21, p. 2917-2932.

Monson, D.H., Doak, D.F., Ballachey, B.E., Johnson, A., and Bodkin, J.L., 2000, Long-term impacts of the Exxon Valdez oil spill on sea otters, assessed through age-dependent mortality patterns: Proceedings of the National Academy of Sciences, v. 97, p. 6562-6567.

Monson, D.H., McCormick, C., and Ballachey, B., 2001, Chemical anesthesia of northern sea otters (Enhydra lutris) - Results of past field studies: Journal of Zoo and Wildlife Medicine, v. 32, p. 181-189.

Morris, B.F., and Loughlin, T.R., 1994, Overview of the Exxon Valdez Oil Spill, 1989-1992, in Loughlin, T.R., ed., Marine Mammals and the Exxon Valdez: San Diego, Academic Press, p. $1-22$.

Oesch-Bartlomowicz, B., Huelster, A., Wiss, O., Antoniou-Lipfert, P., Dietrich, C., Arand, M., Weiss, C., Bockamp, E., and Oesch, F., 2005, Aryl hydrocarbon receptor activation by cAMP vs. dioxin: divergent signaling pathways: Proceedings of the National Academy of Sciences, v. 102, p. 9218-9223.

Peterson, C.H., and Holland-Bartels, L., 2002, Nearshore vertebrate predators: constraints to recovery from oil pollution: Marine Ecology Progress Series, v. 241, p. 235-236. 
Peterson, C.H., Rice, S.D., Short, J.W., Esler, D., Bodkin, J.L., Ballachey, B.E., and Irons, D.B., 2003, Long-term ecosystem response to the Exxon Valdez oil spill: Science, v. 302, no. 5653, p. 2082-2086.

Quesenberry, C.P., and Hurst, D.C., 1964, Large sample simultaneous confidence intervals for multinomial proportions: Technometrics, v. 6, p. 191-195.

Quintana, F.J., Basso, A.S., Iglesias, A.H., Korn, T., Farez, M.F., Bettelli, E., Caccamo, M., Oukka, M., and Weiner, H.L., 2008, Control of T(reg) and T(H)17 cell differentiation by the aryl hydrocarbon receptor: Nature, v. 453, p. 6-7.

Raisuddin, S., Kwok, K.W.H., Leung, K.M.Y., Schlenk, D., and Lee, J., 2007, The copepod Tigriopus - A promising marine model organism for ecotoxicology and environmental genomics: Aquatic Toxicology, v. 83, p. 161-173.

Ricca, M.A., Miles, A.K., Ballachey, B.E., Bodkin, J.L., Esler, D., and Trust, K.A., 2010, PCB exposure in sea otters and harlequin ducks in relation to history of contamination by the Exxon Valdez oil spill: Marine Pollution Bulletin, v. 60, p. 861-872.

Rice, S.D., Short, J.W., Carls, M.G., Moles, A., and Spies, R.B., 2007, The Exxon Valdez oil spill, in Spies, R., ed., Long-term ecological change in the northern Gulf of Alaska: Elsevier, p. 417-520.

Riedman, M.L., and Estes, J.A., 1990, The sea otter (Enhydra lutris)-Behavior, ecology, and natural history: U.S. Fish and Wildlife Service Biological Report 90, p. 1-126.

Rigopoulou, E.I., Abbott, W.G., Haigh, P., and Naoumov, N.V., 2005, Blocking of interleukin10 receptor-a novel approach to stimulate T-helper cell type 1 responses to hepatitis $\mathrm{C}$ virus: Clinical Immunology, v. 117, p. 57-64.

Schneider, K.B., 1973, Age determination of sea otters: Alaska Department of Fish and Game, Federal Aid in Wildlife Restoration Projects W-17-4 and W-17-5, Progress Report, 23 p. Short, J.W., Irvine, G.V., Mann, D.H., Maselko, J.M., and others, 2007, Slightly weathered Exxon Valdez oil persists in Gulf of Alaska beach sediments after 16 years: Environmental Science and Technology, v. 41, p. 1245-1250.

Short, J.W., Lindeberg, M.R., Harris, P.A., Maselko, J.M., and others, 2004, Estimate of oil persisting on beaches of Prince William Sound, 12 years after the Exxon Valdez oil spill: Environmental Science and Technology, v. 38, p.19-25.

Short, J.W., Maselko, J.M., Lindeberg, M.R., Harris, P.M., and Rice, S.D., 2006, Vertical distribution and probability of encountering intertidal Exxon Valdez oil on shorelines of three embayments within Prince William Sound, Alaska: Environmental Science and Technology, v. 40, p. 3723-3729.

Siler, W., 1979, A competing-risk model for animal mortality: Ecology, v. 60, p. 750-757.

Siniff, D.B., William, T.D., Johnson, A.M., and Garshelis, D.L., 1982, Experiments on the response of sea otters Enhydra lutris to oil: Biological Conservation v. 23, p. 261-272.

Sokal, R.R., and Rohlf, F.J., 1995, Biometry, 3rd ed.: New York, W.H. Freeman and Company. Spies, R.B., Rice, S.D., Wolfe, D.A., and Wright, B.A., 1996, The effects of the Exxon Valdez

Oil Spill on the Alaskan coastal environment, in Rice, S.D., Spies, R.B., Wolfe, D.A., Wright, B.A., eds., Proceedings of the Exxon Valdez oil spill symposium: American Fisheries Society Symposium 18, p. 1-16.

Squire, L.R., and others, 2008, Fundamental Neuroscience, 3rd ed.: Amsterdam, Elsevier /Academic Press, 143 p. 
Stott, J.L., and McBain, J.F., 2012, Longitudinal monitoring of immune system parameters of cetaceans and application to their health management, in Miller, R.E., Fowler, M.E., eds., Fowler's Zoo and Wild Animal Medicine Current Therapy, Volume 7: Saunders, p. 482-489. Tabuchi, M., Veldhoen, N., Dangerfield, N., Jeffries, S., Helbing, C.C., and Ross, P.S., 2006, PCB-related alteration of thyroid hormones and thyroid hormone receptor gene expression in free-ranging harbor seals (Phoca vitulina): Environmental Health Perspectives, v. 114, p. 1024-1031.

Tanabe, S., Iwata, H., and Tatsukawa, R., 1994, Global contamination by persistent organochlorines and their ecotoxicological impact on marine mammals: Science of the Total Environment, v. 154, p. 163-177.

Thomas, R.E., Lindeberg, M., Harris, P.M., and Rice, S.D., 2007, Induction of DNA strand breaks in the mussel (Mytilus trossulus) and clam (Protothaca staminea) following chronic field exposure to polycyclic aromatic hydrocarbons from the Exxon Valdez spill: Marine Pollution Bulletin, v. 54, p. 726-732.

Trust, K.A., Esler, D., Woodin, B.R., and Stegeman, J.J., 2000, Cytochrome P4501A induction in sea ducks inhabiting nearshore areas of Prince William Sound, Alaska: Marine Pollution Bulletin, v. 40, p. 397-403.

Tsai, M.J., and O’Malley, B.W., 1994, Molecular mechanisms of action of steroid/thyroid receptor superfamily members: Annual Review of Biochemistry, v. 63, p. 451-486.

Tsan, M., and Gao, B., 2004, Cytokine function of heat shock proteins: American Journal of Physiology-Cell Physiology, v. 286, p. C739-C744.

Tumpey, T.M., Szretter, K.J., Van Hoeven, N., Katz, J.M., Kochs, G., Haller, O., Garcia-Sastre, A., and Staeheli, P., 2007, The Mx1 gene protects mice against the pandemic 1918 and highly lethal human H5N1 influenza viruses: Journal of Virology, v. 81, p. 10818-10821.

Tuynder, M., Fiucci, G., Prieur, S., Lespagnol, A., Geant, A., Beaucourt, S., Duflaut, D., Besse, S., Susini, L., Cavarelli, J., Moras, D., Amson, R., and Telerman, A., 2004, Translationally controlled tumor protein is a target of tumor reversion: Proceedings of the National Academy of Sciences, USA, v. 101, p. 15364-15369.

Udevitz, M.S., and Ballachey, B.E., 1998, Estimating survival rates with age-structure data: Journal of Wildlife Management, v. 62, p. 779-792.

Veldhoen, M., Hirota, K., Westendorf, A.M., Buer, J., Dumoutier, L., Renauld, J.C., and Stockinger, B., 2008, The aryl hydrocarbon receptor links TH17-cell-mediated autoimmunity to environmental toxins: Nature, v. 453, p. 106-109.

Wegner, K.M., Kalbe, M., Rauch, G., Kurtz, J., Schaschl, H., and Reusch, T.B.H., 2006, Genetic variation in MHC class II expression and interactions with $\mathrm{MHC}$ sequence polymorphism in three-spined sticklebacks: Molecular Ecology, v. 15, p. 1153-1164.

Xia, Y., Li, H.L., Boufadel, M.C., and Sharifi, Y., 2010, Hydrodynamic factors affecting the persistence of the Exxon Valdez oil in a shallow bedrock beach: Water Resources Research, v. 46, p. W10528.

Zheng, S., Song, Y., Qiu, X., Sun, T., Ackland, M.L., and Zhang, W., 2008, Annetocin and TCTP expressions in the earthworm Eisenia fetida exposed to PAHs in artificial soil: Ecotoxicology and Environmental Safety, v. 71, p. 566-573. 


\section{Appendix 1. Publications and Reports on Sea Otter Oil Spill Studies, Authored or Co-authored by USGS Scientists, 1989-2013}

Ballachey, B.E., 1995, Biomarkers of damage to sea otters in Prince William Sound, Alaska, following potential exposure to oil spilled from the $T / V$ Exxon Valdez: Anchorage, Alaska, U.S. Fish and Wildlife Service Exxon Valdez Oil Spill State/Federal Natural Resource Damage Assessment Final Report, Marine Mammal Study 6-1.

Ballachey, B.E., Bodkin, J.L., and DeGange, A.R., 1994, An overview of sea otter studies, in Loughlin, T.R., ed., Marine mammals and the Exxon Valdez: Academic Press, San Diego, p. 47-59.

Ballachey, B.E., Bodkin, J.L., Howlin, S., Doroff, A.M., and Rebar, A.H, 2003, Correlates to survival of juvenile sea otters in Prince William Sound, Alaska, 1992-93: Canadian Journal of Zoology, no. 81, p. 1494-1510.

Ballachey, B.E., Bodkin, J.L., Howlin, S., Kloecker, K.A., Monson, D.H., Rebar, A.H., and Snyder, P.W., 2002, Hematology and serum chemistry of sea otters in oiled and unoiled areas of Prince William Sound, Alaska, 1996-98-Appendix BIO-01 in Holland-Bartels, L., ed., Mechanisms of impact and potential recovery of nearshore vertebrate predators following the 1989 Exxon Valdez oil spill: U.S. Geological Survey Exxon Valdez Oil Spill Trustee Council Restoration Project Final Report, Restoration Project 95025-98025.

Ballachey, B.E., Bodkin, J.L., and Monson, D.H., 2013, Quantifying long-term risks to sea otters from the 1989 'Exxon Valdez' oil spill: Reply to Harwell and Gentile, Marine Ecology Progress Series, v. 488, p. 297-301.

Ballachey, B.E., and Kloecker, K.A., 1997, Hydrocarbons in hair, livers and intestines of sea otters (Enhydra lutris) found dead along the path of the Exxon Valdez oil spill: Anchorage, Alaska, U.S. Fish and Wildlife Service Exxon Valdez Oil Spill State/Federal Natural Resource Damage Assessment Final Report, Marine Mammal Study 6-3.

Ballachey, B.E., and Kloecker, K.A., 1997, Hydrocarbon residues in tissues of sea otters (Enhydra lutris) collected following the Exxon Valdez oil spill Anchorage, Alaska, U.S. Fish and Wildlife Service Exxon Valdez Oil Spill State/Federal Natural Resource Damage Assessment Final Report, Marine Mammal Study 6-16.

Ballachey, B.E., and Kloecker, K.A., 1997, Hydrocarbon residues in tissues of sea otters (Enhydra lutris) collected from southeast Alaska: Anchorage, Alaska, U.S. Fish and Wildlife Service Exxon Valdez Oil Spill State/Federal Natural Resource Damage Assessment Final Report, Marine Mammal Study 6-2.

Ballachey, B.E., Stegeman, J.J., Snyder, P.W., Blundell, G.M., Bodkin, J.L., Dean, T.A., Duffy, L., Esler, D., Golet, G., Jewett, S., Holland-Bartels, L., Rebar, A.H., Seiser, P.A., and Trust, K.A., 2002, Oil exposure and health of nearshore vertebrate predators in Prince William Sound following the 1989 Exxon Valdez oil spill, chap. 2 in Holland-Bartels, L., ed., Mechanisms of impact and potential recovery of nearshore vertebrate predators following the 1989 Exxon Valdez oil spill: U.S. Geological Survey Exxon Valdez Oil Spill Trustee Council Restoration Project Final Report, Restoration Project 95025-98025.

Bickham, J.W., Mazet, J.A., Blake, J., Smolen, M.J., Lou, Y., and Ballachey, B.E., 1998, Flowcytometric determination of genotoxic effects of exposure to petroleum in mink and sea otters: Ecotoxicology, v. 7, p. 191-199. 
Bodkin, J.L., Ames, J.A., Jameson, R.J., Johnson, A.M., Matson, G.M., 1997, Estimating age of sea otters with cementum layers in the first premolar: Journal Wildlife Management, v. 61, p. 967-973.

Bodkin, J.L., and Ballachey, B.E., 1993, Sea otter research in Alaska-In the wake of the Exxon Valdez: The Otter Raft, v. 49, p. 8-9.

Bodkin, J.L., and Ballachey, B.E., 1996, Monitoring the status of the wild sea otter populationField studies and techniques: Endangered Species Update 13, no. 12, p. 14-19.

Bodkin, J.L., and Ballachey, B.E., 1997, Restoration notebook series-Sea otter: Anchorage, Alaska, Exxon Valdez Oil Spill Trustee Council.

Bodkin, J.L., Ballachey, B.E., Coletti, H.A., Esslinger, G.G., and others, 2012, Long-term effects of the Exxon Valdez oil spill-Sea otter foraging in the intertidal as a pathway of exposure to lingering oil: Marine Ecology Progress Series 447, p. 273-287.

Bodkin, J.L., Ballachey, B.E., Dean, T.A., Fukuyama, A.K., Jewett, S.C., McDonald, L., Monson, D.H., O’Clair, C.E., and Van Blaricom, G.R., 2002, Sea otter population status and the process of recovery from the 1989 'Exxon Valdez' oil spill: Marine Ecology Progress Series, v. 241, p. 237-253.

Bodkin, J.L., Ballachey, B.E., Esler, D., and Dean, T., 2003, Patterns and processes of population change in selected nearshore vertebrate predators: Exxon Valdez Restoration Project //423, Final Report, 80 p.

Bodkin, J.L., Ballachey, B.E., and Esslinger, G.G., 2011, Trends in sea otter population abundance in western Prince William Sound, Alaska-Progress toward recovery following the 1989 Exxon Valdez oil spill: U.S. Geological Survey Scientific Investigations Report 2011$5213,14 \mathrm{p}$.

Bodkin, J.L., and Dean, T.A., 2003, Monitoring in the nearshore-A process for making reasoned decisions: EVOS Restoration Project 030687 Final Report.

Bodkin, J.L., Esler, D.E., Rice, S.D., Matkin, C.O., and Ballachey, B.E., 2013, The effects of spilled oil on coastal ecosystems-Lessons from the Exxon Valdez spill, in Lockwood, J., and Maslo, B., eds., Coastal Conservation: Cambridge University Press.

Bodkin, J.L., Esslinger, G.E., and Ballachey, B.E., 2010, Trends in sea otter population abundance in western Prince William Sound: Progress toward recovery following the 1989 "Exxon Valdez oil spill-Exxon Valdez Restoration Project //0808-Draft Final Report: Anchorage, Alaska, Exxon Valdez Restoration Office, 112 p.

Bodkin, J.L., Monson, D.H., and Esslinger, G.G., 2007, Population status and activity budgets derived from time-depth recorders in a diving mammal: Journal of Wildlife Management, $v$. 71, p. 2034-2044.

Bodkin, J.L., Mulcahy, D., and Lensink, C., 1993, Age-specific reproduction in female sea otters (Enhydra lutris) from south-central Alaska-analysis of reproductive tracts: Canadian Journal of Zoology, v. 71, p. 1811-1815.

Bodkin, J.L., Mulcahy, D., and Lensink, C., 1996, Age-specific reproduction in female sea otters (Enhydra lutris) from southcentral Alaska-Analysis of reproductive tracts: Anchorage, Alaska, U.S. Fish and Wildlife Service Exxon Valdez Oil Spill State/Federal Natural Resource Damage Assessment Final Report, Marine Mammal Study 6-4.

Bodkin, J.L., and Udevitz, M.S., 1994, An intersection model for estimating sea otter mortality along the Kenai Peninsula, in Loughlin, T.R., ed., Marine mammals and the Exxon Valdez: San Diego, Academic Press, p. 81-95. 
Bodkin, J.L., and Udevitz, M.S., 1995, An intersection model for estimating sea otter mortality from the Exxon Valdez oil spill along the Kenai Peninsula, Alaska: Anchorage Alaska, U.S. Fish and Wildlife Service Exxon Valdez Oil Spill State/Federal Natural Resource Damage Assessment Final Report, Marine Mammal Study 6-5, 15 p.

Bodkin, J.L., and Udevitz, M.S., 1999, An aerial survey method to estimate sea otter abundance, in Garner, G.W., Amstrup, S.C., Laake, J.L., Manly, B.J.F., McDonald, L.L., and Robertson, D.G., eds., Marine mammal survey and assessment methods: Rotterdam, Netherlands, AA Balkema, p. 13-26.

Bowen, L., Miles, A.K., Murray, M., Haulena, M., Tuttle, J., Van Bonn, W., Adams, L., Bodkin, J.L., Ballachey, B.E., Estes, J., Tinker, M.T., Keister, R.R., and Stott, J.L., 2011, Gene transcription in sea otters (Enhydra lutris) - Development of a diagnostic tool for sea otter and ecosystem health: Molecular Ecology Resources, v. 12, p. 67-74.

Burn, D.M., 1994, Boat-based population surveys of sea otters in Prince William Sound, in Loughlin, T.R., ed., Marine mammals and the Exxon Valdez: San Diego, Academic Press, p. 61-80.

Dean, T.A., Bodkin, J.L., Fukuyama, A.K., Jewett, S.C., Monson, D.H., O'Clair, C.E., and VanBlaricom, G.R., 2002, Food limitation and the recovery of sea otters following the Exxon Valdez oil spill: Marine Ecology Progress Series, v. 241, p. 255-270.

Dean, T.A., Bodkin, J.L., Fukuyama, A.K., Jewett, S.C., Monson, D.H., O'Clair, C.E., and VanBlaricom, G.R., 2002, Sea otter (Enhydra lutris) perspective-Mechanisms of impact and potential recovery of nearshore vertebrate predators following the 1989 Exxon Valdez oil spill-Part B. Food limitation and the recovery of sea otters in Prince William Sound, in Holland-Bartels, L.E., ed., Mechanisms of impact and potential recovery of nearshore vertebrate predators following the 1989 Exxon Valdez oil spill: U.S. Geological Survey Exxon Valdez Oil Spill Trustee Council Restoration Project Final Report, Restoration Project 9502599025, p 3B.1-3B.41.

Dean, T.A., Bodkin, J.L., Jewett, S.C., Monson, D.H., and Jung D., 2000, Changes in sea urchins following a reduction in sea otter density as a result of the Exxon Valdez oil spill: Marine Ecology Progress Series, v. 199, p. 281-291.

DeGange, A.R, Ballachey, B.E., and Bayha, K., 1995, Release strategies for rehabilitated sea otters, chap. 14 in Williams, T.M., and Davis, R.W., eds., Emergency care and rehabilitation of oiled sea otters - A guide for oil spills involving fur-bearing marine mammals: Fairbanks, University of Alaska Press.

DeGange, A.R., Doroff, A,M., and Monson, D.H., 1994, Experimental recovery of sea otter carcasses at Kodiak island, Alaska, following the Exxon Valdez oil spill: Marine Mammal Science, v. 10, p. 492-496.

DeGange, A.R., Douglas, D.C., Monson, D.H., and Robbins, C.M., 1995, Surveys of sea otters in the Gulf of Alaska in response to the Exxon Valdez oil spill: Anchorage, Alaska, U.S. Fish and Wildlife Service Exxon Valdez Oil Spill State/Federal Natural Resource Damage Assessment Final Report, Marine Mammal Study 6-7.

Doroff, A.M., and Bodkin, J.L., 1994, Sea otter foraging behavior and hydrocarbon levels in prey, in Loughlin, T.R., ed., Marine mammals and the Exxon Valdez: San Diego, Academic Press, p. 193-208. 
Doroff, A.M., and DeGange, A.R., 1995, Experiments to determine drift patterns and rates of recovery of sea otter carcasses following the Exxon Valdez oil spill: Anchorage, Alaska, U.S. Fish and Wildlife Service Exxon Valdez Oil Spill State/Federal Natural Resource Damage Assessment Final Report, Marine Mammal Study 6-9.

Esslinger, G.G., 2011, Temporal patterns in the behavior and body temperature of sea otters in Alaska: Anchorage, University of Alaska, M.S. Thesis.

Esslinger, G.G., Bodkin, J.L., Breton, A.R., Burns, J.M., and Monson, D.H., in press, Temporal patterns in the foraging behavior of sea otters in Alaska: Journal of Wildlife Management.

Garrott, R.A., Eberhardt, L.L., and Burn, D.M., 1993, Mortality of sea otters in Prince William Sound following the Exxon Valdez oil spill: Marine Mammal Science, v. 9, no. 4, p. 343-359.

Holland-Bartels, L.E., ed., 2002, Mechanisms of impact and potential recovery of nearshore vertebrate predators following the 1989 Exxon Valdez oil spill, volume 1: U.S. Geological Survey Exxon Valdez Oil Spill Trustee Council Restoration Project Final Report, Restoration Project 95025-99025.

Holland-Bartels, L.E., ed., 2002, Mechanisms of impact and potential recovery of nearshore vertebrate predators following the 1989 Exxon Valdez oil spill, volume 2, appendices: U.S. Geological Survey Exxon Valdez Oil Spill Trustee Council Restoration Project Final Report, Restoration Project 95025-99025.

Lipscomb, T.P., Harris, R.K., Moeller, R.B., Pletcher, J.M., Haebler, R.J., and Ballachey, B.E., 1993, Histopathologic lesions in sea otters exposed to crude oil: Veterinary Pathology Online, v. 30 , p. $1-11$.

Lipscomb, T.P., Harris, R.K., Moeller, R.B., Pletcher, J.M., Haebler, R.J., and Ballachey, B.E., 1996, Histopathologic lesions associated with crude oil exposure in sea otters: Anchorage, Alaska, U.S. Fish and Wildlife Service Exxon Valdez Oil Spill State/Federal Natural Resource Damage Assessment Final Report, Marine Mammal Study 6-10.

Lipscomb, T.P., Harris, R.K., Rebar, A.H., Ballachey, B.E., and Haebler, R.J., 1994, Pathology of sea otters - chap. 16 in Loughlin, T.R., ed., Marine mammals and the Exxon Valdez: Academic Press.

Lipscomb, T.P., Harris, R.K., Rebar, A.H., Ballachey, B.E., and Haebler, R.J., 1996, Pathological studies of sea otters: Anchorage, Alaska, U.S. Fish and Wildlife Service Exxon Valdez Oil Spill State/Federal Natural Resource Damage Assessment Final Report, Marine Mammal Study 6-11.

Loughlin, T.R., Ballachey, B.E., and Wright, B., 1996, Overview of studies to determine injury caused by the Exxon Valdez oil spill to marine mammals, in Rice, S.D., Spies, R.B., Wolfe, D.A., and Wright, B.A., eds., Proceedings of the Exxon Valdez Oil Spill Symposium: American Fisheries Society Symposium 18, p. 798-808.

Miles, A.K., Bowen, L., Ballachey, B.E., Bodkin, J.L., and others, 2012, Variation in transcript profiles in sea otters (Enhydra lutris) from Prince William Sound, Alaska and clinically normal reference otters: Marine Ecology Progress Series 451, p. 201-212.

Monnett, C.M., and Rotterman, L.M., 1995, Mortality and reproduction of female sea otters in Prince William Sound, Alaska: Anchorage, Alaska, U.S. Fish and Wildlife Service Exxon Valdez Oil Spill State/Federal Natural Resource Damage Assessment Final Report, Marine Mammal Study 6-13. 
Monnett, C., and Rotterman, L.M., 1995, Mortality and reproduction of sea otters oiled and treated as a result of the T/V Exxon Valdez oil spill: Anchorage, Alaska, U.S. Fish and Wildlife Service Exxon Valdez Oil Spill State/Federal Natural Resource Damage Assessment Final Report, Marine Mammal Study 6-14.

Monnett, C., and Rotterman, L.M., 1995, Movements of weanling and adult female sea otters in Prince William Sound, Alaska, after the T/V Exxon Valdez oil spill: Anchorage, Alaska, U.S. Fish and Wildlife Service Exxon Valdez Oil Spill State/Federal Natural Resource Damage Assessment Final Report, Marine Mammal Study 6-12.

Monson, D.H., and Ballachey, B.E., 1996, Age distributions of sea otters found dead in Prince William Sound, Alaska, following the Exxon Valdez oil spill, Exxon Valdez Oil Spill State/Federal Natural Resource Damage Assessment Final Report (Marine Mammal Study 615), U.S. Fish and Wildlife Service, 1011 E. Tudor Road, Anchorage, Alaska.

Monson, D.H., Doak, D.F., Ballachey, B.E., and Bodkin, J.L., 2011, Effect of the Exxon Valdez oil spill on the sea otter population of Prince William Sound, Alaska-Do lingering oil and source-sink dynamics explain the long-term population trajectory?: Ecological Applications, v. 21, p. 2917-2932.

Monson, D.H., Doak, D.F., Ballachey, B.E., Johnson, A., and Bodkin, J.L., 2000, Long-term impacts of the Exxon Valdez oil spill on sea otters, assessed through age-dependent mortality patterns: Proceedings of the National Academy of Sciences, v. 97, p. 6562-6567.

Mulcahy, D.M., and Ballachey, B.E., 1994, Hydrocarbon residues in sea otters, chap. 18 in Loughlin, T.R., ed., Marine mammals and the Exxon Valdez: Academic Press.

Peterson, C.H., Rice, S.D., Short, J.W., Esler, D., Bodkin, J.L., Ballachey, B.E., and Irons, D.B., 2003, Long-term ecosystem response to the Exxon Valdez oil spill: Science, v. 302, no. 5653, p. 2082-2086.

Rebar, A.H., Ballachey, B.E., Bruden, D.L., and Kloecker, K.A., 1996, Hematology and clinical chemistry of sea otters captured in Prince William Sound, Alaska, following the Exxon Valdez oil spill: Anchorage, Alaska, U.S. Fish and Wildlife Service NRDA Report, Marine Mammal Study 6.

Rebar, A.H., Lipscomb, T.P., Harris, R.K., and Ballachey, B.E., 1995, Clinical and clinical laboratory correlates in sea otters dying acutely in rehabilitation centers: Veterinary Clinical Pathology, v. 32, p.346-350.

Ricca, M.A., Miles, A.K., Ballachey, B.E., Bodkin, J.L., Esler, D.E., and Trust, K.A., 2010, PCB exposure in sea otters and harlequin ducks in relation to history of contamination by the Exxon Valdez oil spill: Marine Pollution Bulletin, v. 60, no. 6, p. 861-872.

Udevitz, M.S., and Ballachey, B.E., 1998, Estimating survival rates with age structure data: Journal of Wildlife Management, v. 62, no. 2, p. 779-792.

Udevitz, M.S., Ballachey, B.E., and Bruden, D.L., 1996, A population model for sea otters in western Prince William Sound: Anchorage, Alaska, National Biological Service Exxon Valdez Oil Spill Federal/State Restoration Project Final Report, Restoration Project 93043-3, 34 p.

Udevitz, M.S., Bodkin, J.L., and Costa, D., 1995, Detection of sea otters in boat-based surveys of Prince William Sound, Alaska: Anchorage, Alaska, U.S. Fish and Wildlife Service Exxon Valdez Oil Spill State/Federal Natural Resource Damage Assessment Final Report, Marine Mammal Study 6-19.

Udevitz, M.S., Bodkin, J.L., and Costa, D., 1995, Detection of sea otters in boat-based surveys of Prince William Sound, Alaska: Marine Mammal Science, v. 11, p. 59-71. 
VanBlaricom, G.R., Fukuyama, A.K., O'Clair, C.E., Monson, D.H., Jewett, S.C., Gage, T.K., Dean, T.A., and Bodkin, J.L., 2002 Sea otter (Enhydra lutris) perspective-Mechanisms of impact and potential recovery of nearshore vertebrate predators following the 1989 Exxon Valdez oil spill-Part C. Symmetry of trophic linkages among sea otters and their prey in Prince William Sound, Alaska-Evidence in the aftermath of the Exxon Valdez oil spill in Holland-Bartels, L.E., ed., Mechanisms of impact and potential recovery of nearshore vertebrate predators following the 1989 Exxon Valdez oil spill: U.S. Geological Survey Exxon Valdez Oil Spill Trustee Council Restoration Project Final Report, Restoration Project 9502599025, p. 3CA.1-3C.57. 
This page left intentionally blank 
Publishing support provided by the U.S. Geological Survey Publishing Network, Tacoma Publishing Service Center

For additional information contact: Director, Alaska Science Center U.S. Geological Survey 4210 University Dr.

Anchorage, Alaska 99508-4560

http://alaska.usgs.gov 
